\title{
ARQUiTECTURA DE ASENTAMIENTOS DE LA COSTA DE TARAPACÁ, NORTE DE CHILE
}

\author{
Simón Urbina ${ }^{1}$, Leonor Adán ${ }^{2}$, Cora Moragas ${ }^{3}$, Sebastián Olmos ${ }^{4}$ y Rolando Ajata ${ }^{5}$
}

\begin{abstract}
Resumen
Se presenta el estudio sobre patrones de asentamiento y arquitectura doméstica para la costa desértica de Tarapacá (norte de Chile). Se analizan los registros constructivos de ocho sitios ubicados entre Pisagua y la desembocadura del río Loa $\left(c a .19^{\circ} 55^{\prime}-21^{\circ} 43^{\prime} \mathrm{S}\right.$.), así como nuevos contextos datados en Punta Patache, que amplían el conocimiento sobre las ocupaciones formativas en la zona. Se discute la variabilidad de los patrones arquitectónicos identificados para finalmente plantear el desarrollo de una Tradición Arquitectónica Costera para el período Formativo (900 AC - $900 \mathrm{DC}$ ), que expresa las innovaciones y transformaciones percibidas por las sociedades costeras de Tarapacá.
\end{abstract}

Palabras claves: asentamientos - arquitectura - tradición arquitectónica costera - período Formativo - Tarapacá.

\begin{abstract}
We present a study of settlement patterns and domestic architecture for the Tarapacá Coast $\left(c a \cdot 19^{\circ} 55^{\prime}-21^{\circ} 43^{\prime}\right.$ S.). We expose new formative evidence and radiocarbon dates from Patache Peninsula sites and full construction database analysis from eight sites located between Pisagua and the Loa river. We discuss the variability of domestic buildings to argue a durable Coastal Architectonic Tradition during the Formative Period ( $900 \mathrm{BD}-900 \mathrm{AD}$ ), that points out long term changes and household innovation process inside coastal societies of Tarapacá.
\end{abstract}

Key words: settlements - architecture - coastal architectonic tradition Formative period - Tarapacá.

Recibido: abril 2010. Aceptado: junio 2010.

\section{* Introducción}

Varios estudios han insistido en la importancia del sustrato arcaico costero en Tarapacá (norte de Chile), sustentado en la caza y recolección con un patrón de asentamiento y movilidad tanto longitudinal como hacia el interior (Núñez 1979; Meighan y True 1980; Olmos y Sanhueza 1984). Sin embargo, poco se ha avanzado en la documentación de asentamientos habitacionales fuera del ámbito específico de las quebradas de Tarapacá y Guatacondo. Tampoco se ha ofrecido una mirada intersitios que permita un estudio regional, incluyendo aquellos asentamientos menos densos y dispersos de la costa desértica de Tarapacá entre los años $900 \mathrm{AC}$ y $900 \mathrm{DC}$.

Este trabajo contribuye con nuevas evidencias para revertir esta desigual imagen del pasado y para aportar al estudio de la arquitectura formativa de la costa de Tarapacá entre la desembocadura de la quebrada de Camarones y el río Loa. Específicamente, se espera: 1) caracterizar parte de la variabilidad arquitectónica de los sistemas sociales costeros como elemento clave para la comprensión de los desarrollos formativos de la región, y 2) reflexionar acerca del rol de la arquitectura doméstica en la producción de nuevos órdenes económicos y sociales.

En la primera sección presentamos nuestro enfoque de investigación y las características geográficas y ambientales de la costa desértica de Tarapacá. Luego, en la sección de resultados ofrecemos información inédita sobre asentamientos datados en la localidad de Patache así como

\footnotetext{
${ }^{1}$ Becario CONICYT. Universidad Austral de Chile. Casilla 787, Valdivia, CHILE. Email: simon.urbina@uach.cl

2 Universidad Austral de Chile. Casilla 586, Valdivia, CHILE. Email: ladan@uach.cl

3 Sociedad Chilena de Arqueología. Av. Chipana, Pasaje 4, 3428, Iquique, CHILE. Email: cmoragas@vtr.net

4 Universidad Bolivariana. Baquedano 1470, Iquique, CHILE. Email: sebaxolmos@gmail.com

5 Universidad de Tarapacá. General Velásquez 1775, Arica, CHILE. Email: rolandoajata@gmail.com
} 
el análisis arquitectónico efectuado en las localidades de Pisagua, Caleta Los Verdes, Caleta Sarmenia, Pabellón de Pica, Punta Chomache, Punta Blanca y Caleta Loa. En la última sección, discutimos las características y patrones de asentamiento identificados y sus vínculos regionales. Se evalúa la hipótesis de que ciertos elementos y rasgos arquitectónicos utilizados por las poblaciones costeras de Tarapacá permanecieron invariables y comunes a la región desde el período Arcaico Tardío en adelante; mientras que otros variaron en los diferentes momentos y asentamientos (Duke 1996), denotando las transformaciones sociales más relevantes experimentadas durante la Tradición Arquitectónica Formativa que perduraría por siglos en la costa desértica del norte de Chile.

\section{* Aproximación arqueológica al área DE ESTUdio}

Una de las expectativas de esta investigación es consolidar una metodología de análisis arquitectónico e histórico que, utilizando como unidad el asentamiento, permita hacer inferencias sobre la organización social de las culturas (Chang 1976) y sus relaciones sociales "utilizando datos arqueológicos [...] y la investigación de los aspectos sincrónicos o estructurales, y diacrónicos o del desarrollo de esas relaciones" (Trigger 1967: 151). Con este propósito, los tipos de asentamiento a nivel de la comunidad han sido utilizados operacionalmente para: a) analizar y reunir modelos estructurales de conductas culturales y sociales en comunidades particulares, y b) proveer una base comparativa intercomunitaria para determinar relaciones históricas (Chang 1968: 5).

Desde esta perspectiva, nos propusimos comprender las manifestaciones arquitectónicas en la costa de Tarapacá. Se estima que las construcciones formativas del Norte Grande, no solo reflejan la adaptación a un clima (costero, ballestero o altiplánico), sino también las habilidades y tecnología de sus constructores, ciertas preferencias estéticas arraigadas, e innovaciones importadas o promocionadas desde ámbitos rituales (Parker Pearson 1982; Hodder 1990), que lentamente pudieron ser integradas como rasgos conspicuos de las estructuras domésticas (Adán y Urbina 2007). En este contexto, es esperable que las unidades domésticas costeras de Tarapacá promovieran desde el período Arcaico distintas clases de transformaciones arquitectónicas, producto de factores socioculturales, físico-climáticos u otras modificaciones.

Por lo tanto, las condiciones ecológicas particulares, así como el tipo de organización social que se puede inferir a través del estudio de los asentamientos del período Formativo (900 AC-900 DC), deberán ser considerados indicadores de los patrones de asentamiento en esta costa. ${ }^{6}$ El tamaño, la forma, los materiales y las tecnologías constructivas utilizadas en la arquitectura de las unidades domésticas o en un conjunto de ellas, se considerarán indicadores directos de la estructura, organización, complejidad social y evolución histórica de un grupo que habita y conoce un espacio durante un largo período (Trigger 1968; Castro et al. 1993).

\section{* La costa desértica del norte de chile}

La costa desértica se extiende entre $18^{\circ} 21^{\prime}$ y $27^{\circ}$ Lat. S. y se ubica entre la frontera chileno-peruana por el norte y el río Copiapó por el sur. Según Paskoff (1978-79), se la puede dividir en dos sectores. De Arica a Iquique, el acantilado costero varía en altura entre 400 y 1000 $\mathrm{m}$, interrumpido solo por tres cursos de agua que bajan desde la cordillera de los Andes hasta el océano Pacífico: las quebradas de Vítor, de río Camarones y de Tana. Hacia el sur, entre Iquique y la desembocadura del río Loa, el acantilado se presenta como un "acantilado muerto" ya que es menos abrupto. A sus pies se extiende una terraza de 2 a $3 \mathrm{~km}$ de ancho, salvo en los lugares donde se encuentran promontorios rocosos que penetran en el mar.

Los principales modelos de ocupación de la costa del Norte Grande de Chile se han enfocado en el ambiente, utilizando las diferencias geográficas y principalmente los recursos hídricos como una variable explicativa de las ocupaciones humanas (Núñez y Varela 1967-68; Núñez 1983; Llagostera 1989). Para Núñez (1983) existirían al menos dos situaciones espaciales que tendrían relación

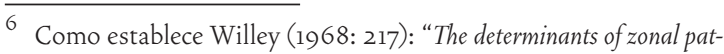
terns, or macropatterns, also include natural environmental and naturalresource conditions. What we are contemplating here is the phenomenon of the culture area. Trade, particulary in raw material, helps set limit to zonal pattern. Political organization, warfare or the lack of it, the invasions of foreign peoples, and religious and ideational factors are all to be considered".
} 


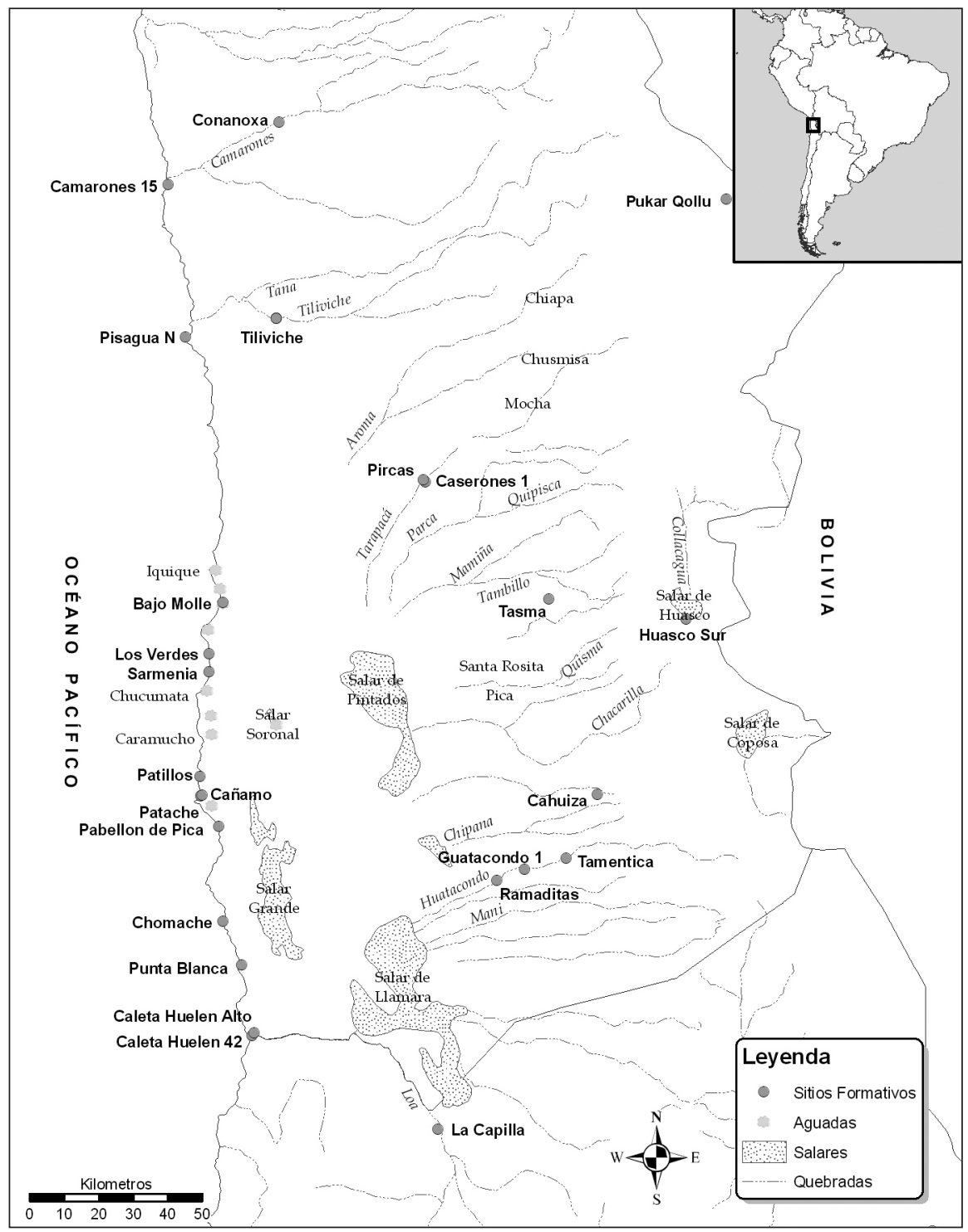

Figura 1. Mapa que indica la ubicación de los principales sitios formativos de Tarapacá.

con el poblamiento prehispánico de la costa del Norte Grande. La costa de Arica o "costa fértil" se caracteriza por sectores de desembocadura de ríos que cruzan el desierto extremo desde sus cabeceras andinas, proporcionando biomas de oasis donde se concentran recursos de caza y recolección terrestre junto con la posibilidad de una intensa explotación del mar gracias a las aguas frías de la corriente de Humboldt. Es un ambiente desértico que carece de lluvias pero es atenuado por la abundante humedad relativa y por neblinas rasantes que humedecen las cotas altas de la cordillera de la Costa, estimulando una cubierta vegetacional permanente conocida como "oasis de niebla".

En las planicies de la costa hiperárida desde Pisagua al sur se establecieron diversos asentamientos con recursos predominantemente marítimos. Los recursos biovegetales provienen casi exclusivamente de la cordillera de la Costa y la concentración de hábitats se rige por la presencia de vertientes de poco caudal. La carencia de sistemas 
fluviales condujo a un patrón de asentamiento disperso en lugares próximos a las vertientes de agua, tales como Iquique, Bajo Molle, Los Verdes, Caramucho, Patillos, Cáñamo, Chipana, entre otros (Figura 1). Por otra parte, la humedad ambiental aumenta la acción de las neblinas rasantes generando sobre la cordillera una cubierta vegetacional con especies comestibles, también útil para el forraje de animales. La serie de aguadas ya nombradas se formaron a partir de fallas geológicas provenientes principalmente de las pampas. Las aguadas que estarían vinculadas con asentamientos humanos prehispánicos serían Aguada de Iquique, Aguada de Bajo Molle, Aguada de Punta Gruesa, Aguada de Chucumata, Aguada Alto Barranco, Aguada del Soronal, Aguada Aguadita y Aguada Punta de Lobos (Núñez y Varela 1967-68). Niemeyer y Cereceda señalan también que:

"Entre Iquique y Antofagasta la mayoría de estas aguadas, ligadas a fallas transversales de la cordillera costera, están inactivas y presentan señales de que en ellas antaño hubo escurrimiento por los restos de ocupación humana. Otras, las aguadas de Colorado en Iquique, Bajo Molle, Chucumata, Pabellón de Pica, todavía presentan afloramientos, pero de muy bajo caudal y deficiente calidad" (1984: 83).

Las poblaciones prehispánicas pudieron obtener recursos hídricos a través de captación de aguas de neblinas (Navarro et al. 2010), tal como se ha investigado en el sector Alto Patache, al sur de Iquique, donde se darían las condiciones óptimas para ello. Las evidencias materiales encontradas (fragmentos cerámicos sobre $515 \mathrm{~m}^{2}$ ) avalarían esta alternativa, complementaria a la de las aguadas, y permitirían explicar el sostenimiento de poblaciones permanentes en la costa desértica de Tarapacá. Los autores señalan:

“[...] el sitio 'Aguada' se ubica a una altitud de 750 msnm en la cima de la ladera sur de Punta Patache, está constituido de una gran roca granítica con una cara vertical plana, con una superficie de alrededor de $12 \mathrm{~m}^{2}$, cuy orientación es totalmente perpendicular a la dirección del viento predominante $\left(180^{\circ} \mathrm{Az}\right)$ y cuya velocidad media es de 1-5 m/s. En este sitio, el volumen de agua captada en 30 días, en el mes de julio del año 2006, fue de $46.72 \mathrm{l} / \mathrm{m}^{2}$, lo que equivale a $1.6 \mathrm{l} / \mathrm{m}^{2}$ día, monto válido para dicho mes" (Navarro et al. 2010: 8).

En la misma dirección, los estudios de Muñoz y colaboradores (2001) apuntan a los "oasis de niebla" al sur de
Iquique como posibles lugares de recolección de raíces y frutos comestibles, hallados en excavaciones arqueológicas (Vidal y García $2009 \mathrm{Ms}$ ), especialmente en las temporadas en que ocurre el evento de El Niño, cuando aumenta notablemente la cantidad de especies vegetales?

\section{* Arquitectura y asentamientos en la COSTA DE TARAPACÁ}

En la escala de nuestra investigación, hemos considerado el procedimiento utilizado por Trigger (1967: 151, 1968: 55, 74), efectuando un análisis del asentamiento arqueológico en tres niveles: a) desde los edificios individuales o estructuras como indicadores de la organización familiar, especialización productiva y variación de la organización social, b) de la manera en que dichas estructuras se ordenan en un asentamiento o comunidad -información relacionada con la organización de los linajes y la adaptación de la comunidad a su entorno natural y cultural $-y, c$ ) de la distribución de los asentamientos o comunidades en el paisaje, como indicadores generales de la organización sociopolítica, del intercambio y del conflicto intercomunitario, entre otros. Como resumió Willey (1968: 217), "the data of settlement are integrated synchronously by the study and demonstration of the relationship between the cities, towns and hamlets of zonal pattern".

Nuestra metodología intenta avanzar en el tratamiento de los asentamientos formativos en la costa de Tarapacá, sobre la base de un manejo sistemático de datos sobre ellos y su arquitectura a nivel regional. ${ }^{8}$ Con este propósito, se efectuó el análisis comparativo de siete sitios ubicados en el interfluvio Tana/Tiliviche-Loa: Pisagua N, Caleta Los

7 De 12 especies vegetales en años normales, la cifra puede aumentar a 72 en estos períodos.

8 El estudio consideró la aplicación, con modificaciones, de la ficha de registro arquitectónico propuesta para el Pucara de Turi por Castro y colaboradores (1993). Esta ficha junto con la utilización de instrumentos de medición (GPS-Datum WGS 84, brújula y huincha métrica), permitió relevar el 100\% de las estructuras de los sitios seleccionados. Cada ficha arquitectónica consigna: 1) Croquis sin escala y a mano alzada; 2) Planta: Forma, dimensiones y superficie (medidas en metros); 3 ) Paramentos: Hilada, aparejo, aplomo, materiales; 4) Vanos: Puertas, acceso, ventanas; 5) Estructuras y elementos complementarios y, 6) Observaciones generales (materiales en superficie, rasgos, etc.). Finalmente se realizó el levantamiento topográfico de los asentamientos. 
Arquitectura de asentamientos de la costa de Tarapacá, norte de Chile

\begin{tabular}{|c|c|c|c|c|c|c|c|}
\hline Sitio & $\begin{array}{c}\text { UTM } \\
\text { Este/Norte }\end{array}$ & Descripción & $\begin{array}{c}\text { Superficie } \\
\left(\mathrm{m}^{2}\right)\end{array}$ & $\begin{array}{l}\text { Unidades } \\
\text { excavadas }\end{array}$ & $\begin{array}{l}\text { Volumen } \\
\left(\mathrm{m}^{3}\right)\end{array}$ & Tipo de depósito & Fechas \\
\hline Patache A & $376321 / 7699801$ & $\begin{array}{c}\text { Basural conchífero } \\
\text { junto a afloramiento } \\
\text { rocoso }\end{array}$ & 314 & $\begin{array}{c}3 \text { cuadrículas de } \\
1 \times 1 \mathrm{~m}\end{array}$ & 1,1 & $\begin{array}{l}\text { Estrato cultural café de } 20 \mathrm{~cm} \\
\text { sobre fogón de } 15 \mathrm{~cm} \text { de espesor }\end{array}$ & $1625 \pm 70 \mathrm{AP}$ \\
\hline Patache G & $376431 / 7699639$ & $\begin{array}{l}\text { Basural conchífero } \\
\text { Tumba }\end{array}$ & 159 & $\begin{array}{c}4 \text { cuadrículas de } \\
1 \times 1 \mathrm{~m} \\
1 \text { tumba }\end{array}$ & 2,3 & $\begin{array}{l}\text { Estrato cultural café de } 30 \mathrm{~cm} \\
\text { intercalado con fogón. Tumba a } \\
50 \mathrm{~cm} \text { de profundidad }\end{array}$ & $2145 \pm 75 \mathrm{AP}$ \\
\hline Patache M & $376328 / 76999635$ & $\begin{array}{c}\text { Basural conchífero } \\
\text { junto a afloramiento } \\
\text { rocoso }\end{array}$ & 63 & $\begin{array}{c}8 \text { cuadrículas de } \\
1 \times 1 \mathrm{~m}\end{array}$ & 3,2 & $\begin{array}{c}\text { E-I cultural café; } \\
\text { E-II fogón y cenizas con restos } \\
\text { culturales y de alimentos; } \\
\text { E-III cultural }\end{array}$ & $2870 \pm 145 \mathrm{AP}$ \\
\hline Patache N & $376324 / 76994966$ & $\begin{array}{c}\text { Basural conchífero } \\
\text { monticular junto a } \\
\text { afloramiento rocoso }\end{array}$ & 60 & $\begin{array}{c}21 \text { cuadrículas de } \\
1 \times 1 \mathrm{~m}\end{array}$ & 8,4 & $\begin{array}{c}\text { E-I cultural; } \\
\text { E-II semi estéril. Profundidad } \\
\text { máxima } 40 \mathrm{~cm}\end{array}$ & $2575 \pm 90 \mathrm{AP}$ \\
\hline Patache P & $376062 / 7699203$ & $\begin{array}{c}\text { Basural conchífero } \\
\text { plano junto a } \\
\text { afloramiento rocoso }\end{array}$ & 144 & $\begin{array}{c}15 \text { cuadrículas de } \\
1 \times 1 \mathrm{~m}\end{array}$ & 6,0 & $\begin{array}{c}\text { E-I cultural; } \\
\text { E-II semi estéril intercalado con } \\
\text { fogones. Profundidad máxima } \\
\qquad 40 \mathrm{~cm} .\end{array}$ & $3210 \pm 145 \mathrm{AP}$ \\
\hline
\end{tabular}

Tabla 1. Dataciones C14 para los asentamientos de la localidad de Patache. Fuente: Moragas (1996 Ms y 1997 Ms-a).

Verdes, Caleta Sarmenia, Pabellón de Pica, Punta Chomache, Punta Blanca, Caleta Huelén Alto y Caleta Huelén 42 (ver Figura 1). Adicionalmente, hemos integrado información inédita de cinco asentamientos estudiados en Punta Patache por Moragas (1996 Ms, 1997 Ms-a), que avalan distintos episodios formativos en una misma localidad y con lo cual creemos posible comprender mejor la trascendencia de los asentamientos con arquitectura analizados. ${ }^{9}$

9 Se pretende documentar las tradiciones constructivas presentes en los sitios, así como la interacción entre la labor y el costo social de construcción, uso y mantenimiento de las estructuras, manejando variables como envergadura de sitio, superficie construida por sitio $\left(\mathrm{m}^{2}\right)$, densidad edilicia y factor de ocupación de suelo FOS (Raffino 1981). Se ha estimado la energía invertida en cada sitio considerando la superficie intramuros $\left(\mathrm{en}^{2}\right.$ ) en relación al trabajo que demandó el emplazamiento de las estructuras, los tipos de paramentos, el aparejo, el trabajo de los materiales y el acabado de superficie. Utilizamos el índice de superficie construida referido, para entender el grado de inversión arquitectónica y de diferenciación entre los sitios (en cuanto a la reducción y/o ampliación de los espacios intramuros). Esa inversión opera según la energía humana involucrada en la construcción, mantenimiento y uso de los edificios durante su vida útil (McGuire y Schiffer 1983). Este índice complementa al valor que entrega el FOS utilizado por Raffino (1981), que considera el porcentaje de superficie edificada dentro del perímetro del asentamiento, incluyendo los espacios no edificados, entre recintos y vías de circulación. De esta manera puede entenderse mejor la intensidad edificatoria de cada asentamiento. Por último, utilizamos el índice de densidad
En consecuencia, segmentaremos la siguiente sección en los apartados "Asentamientos formativos de Punta Patache" y "Asentamientos y arquitectura costera".

\section{Asentamientos formativos de Punta Patache}

El estudio de Patache es sumamente significativo debido a que corresponde, junto a Cáñamo, a un sector donde se concentran numerosas ocupaciones arcaicas y formativas, entre ellas, el basural monticular con las evidencias más tempranas de cerámica del norte de Chile, datadas por radiocarbón en 870 AC y 860 AC (Núñez y Moragas 1977, 1983; Moragas 1995). En nuestra investigación ha sido de importancia sistematizar la información contextual y cronológica de los sitios estudiados en el sector de Punta Patache (Tabla 1, Figura 2). En esta localidad el litoral es rocoso y abrupto en el lado sur de la península, tornándose más suave hacia el norte, donde contacta con Cáñamo. De acuerdo a la homogeneidad que presentan los sitios arqueológicos en ambas localidades pueden

edilicia para resumir el grado de dispersión o aglutinamiento de las estructuras en un sitio, ya que gradúa con mayor precisión la distancia física entre los edificios en relación a la intensidad ocupacional, si ésta se proyecta sobre un terreno ideal de $100 \mathrm{x}$ $100 \mathrm{~m}$. Este índice facilita, por lo tanto, las comparaciones sistemáticas entre sitios (Adán y Urbina 2007, 2010) y se obtiene dividiendo el número total de estructuras por la superficie en hectáreas del asentamiento analizado ( $\mathrm{n}^{\circ}$ estructuras/has). 


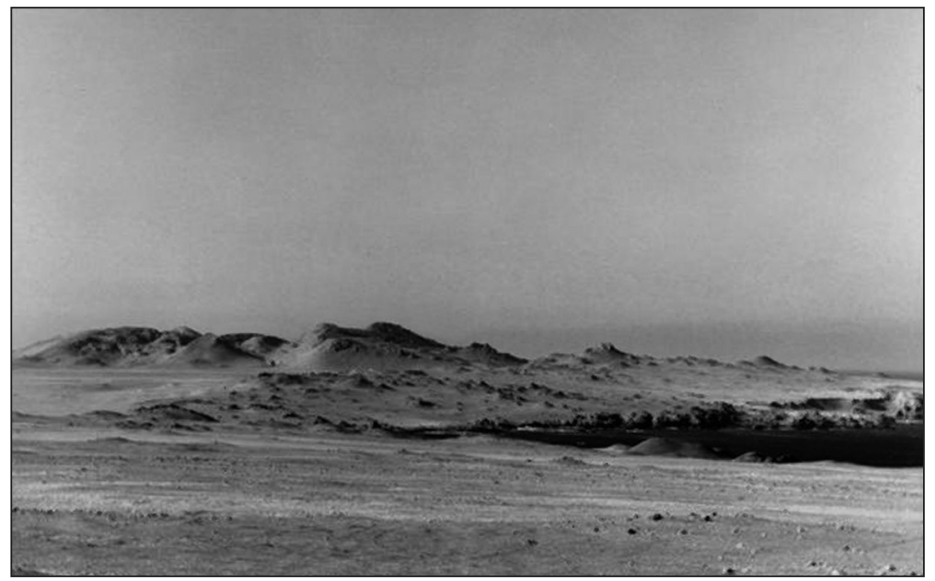

Figura 2. Vista general de Punta Patache.

considerarse como una unidad cultural Cáñamo-Patache. Una característica fundamental de los asentamientos de Patache es la existencia de afloramientos rocosos dispersos que se extienden hacia playa Cáñamo, los que constituyeron elementos de protección y reparo, alrededor de los cuales se concentran numerosos depósitos de restos de alimentos, esencialmente marinos, así como gran cantidad de restos culturales superficiales.

Los sitios registrados en el área de Patache suman 20 y abarcan un amplio rango cronológico (Moragas 1996, 1997a). Para efectos del análisis y en conformidad con el período que nos interesa, contamos con los siguientes asentamientos excavados y con dataciones radicarbónicas:

Patache A. Basural conchífero dispuesto alrededor de un afloramiento rocoso, compuesto por un único estrato cultural de $20 \mathrm{~cm}$ de espesor, ubicado sobre un fogón que llega a $35 \mathrm{~cm}$ de profundidad. Se recuperaron abundantes restos malacológicos, ictiológicos, aves y mamíferos marinos, totora y espinas de cactus. Entre los restos culturales destacan los anzuelos de cactus, cordelería de fibra vegetal, de pelo humano y de lana de camélido de diversos colores, lienzas de algodón, fragmentos de tejidos de lana en colores azul, rojo y café natural; un yesquero con su madero activador, placas de hueso perforadas, sandalia de cuero confeccionada en piel de lobo marino, tablas de madera de cactus con orificios en los bordes (posibles deformadores craneanos), espátula de madera, fragmentos de astas de proyectil, mango de madera con ranura para hoja- cuchillo y desconchadores de mariscos en costillas de lobo marino. También se obtuvieron pequeños marlos de maíz en dos variedades, uno cilíndrico angosto homogéneo y otro cilíndrico ancho adelgazado en ambos extremos. Se recuperaron además, fragmentos de cerámica correspondientes a un puco semiglobular de superficie externa gris alisada y café estriada interior. Se cuenta con una datación radiocarbónica para este sitio de $1625 \pm 70 \mathrm{AP}$ (Geochron Laboratories, Muestra GX-22428; Moragas 1997 Ms-a).

Patache G. Basural conchífero con un estrato único que llega a $30 \mathrm{~cm}$ de profundidad. En las excavaciones se registraron abundantes restos malacológicos, ictiológicos, aves y mamíferos marinos y terrestres. También restos de totora y "argentinas" (bulbo comestible que crece en los cerros costeros). Entre el material cultural destaca la cordelería de fibra vegetal, de camélido y pelo humano; anzuelo de cactus, pesa "cigarro", bolsa de malla de fibra vegetal, fragmentos de cerámica alisada, color café rojizo externo y gris interno y también fragmentos de calabaza. Adyacente al basural, en superficie, hay una estructura circular de 2,5 m de diámetro delimitada con piedras de corrida simple sin argamasa. En su interior se registraron restos subactuales, los cuales se mezclan con restos prehispánicos hasta los $30 \mathrm{~cm}$ de profundidad. A $50 \mathrm{~cm}$ bajo la superficie se registró un esqueleto cuyo cráneo y extremidades superiores estaban removidos; sin embargo, el resto del cuerpo se encontraba intacto. Corresponde a un individuo masculino adulto joven, en posición extendida con el tronco levemente dispuesto sobre el costado derecho. Yacía sobre 
una manta gruesa de fibra de camélido color café claro y trama suelta, de la cual se tomó muestra para datación por radiocarbón. El pubis estaba cubierto con restos de un taparrabo café claro con decorado con motivos escalonados de colores rojo y azul. Entre las ofrendas, además de un plato de cestería sobre los pies, había un punzón de madera, un rollo de piel muy fina y una punta de proyectil de cuarzo blanco de $5 \mathrm{~cm}$ de largo de base escotada. El cráneo conservaba un turbante abultado de hilados de fibra de camélido, típico del período Formativo. La datación radiocarbónica fue de 2145 \pm 75 AP (Geochron Laboratories, Muestra GX-22431; Moragas 1997 Ms-a).

Patache $M$. Basural conchífero de forma semicircular localizado en el faldeo de un afloramiento rocoso. El depósito está compuesto por tres estratos bastante homogéneos respecto del material cultural. El Estrato I es de color café con abundantes restos de moluscos, de aves, pescado y mamíferos marinos; totora, "argentinas" y ramitas. Entre el material cultural, destaca la cordelería de fibra vegetal, de pelo humano y de fibra de camélido de colores naturales y artificiales. También se recuperó una hoja lítica de cuarzo con pedúnculo asimétrico, y otras dos fragmentadas que solo conservan el extremo distal; bolsas anilladas de fibra vegetal asociadas a fragmentos de calabaza, anzuelos de espinas de cactus y fragmentos de cerámica de superficie café gris alisada y café rojo alisada. El Estrato II está compuesto por un fogón nuclear consolidado que se dispersa en cenizas mezcladas con restos malacológicos, ictiológicos, de aves y mamíferos marinos y terrestres. El Estrato III llega a $40 \mathrm{~cm}$ de profundidad y contiene cordelería y bolsas anilladas de fibra vegetal, cordeles de pelo humano y de lana; fragmento de tejido de fibra de camélido café natural, lienzas de algodón, desconchadores de moluscos en costillas de lobo marino, trozos de cierre de bolsa para contener líquido confeccionada en vejiga de lobo marino. En este estrato se recuperaron también anzuelos de espinas de cactus y trozos de piel de ave con plumas pequeñas cosidas para vestimenta (capa). Una muestra obtenida del Estrato III fue datada por radiocarbón dando un resultado 2870£145 AP (Geochron Laboratories, Muestra GX-22434; Moragas 1997 Ms-a).

Patache N. Basural que conforma un montículo bajo, situado al norte de un afloramiento que lo protege de los vientos del sur. Cuenta con dos estratos bastante homogéneos con respecto a sus restos culturales. El Estrato I llega hasta los $15 \mathrm{~cm}$ aunque a veces se embolsona hasta los $30 \mathrm{~cm}$. Registra abundantes restos de moluscos, aves marinas, mamíferos marinos y terrestres; así como gran cantidad de algas, espinas de cactus, totora, "argentinas" y ramitas. Entre el material cultural hay cordeles de fibra vegetal de diversos grosores, trozos de estera de totora, bolsa anillada de fibra vegetal, fibra macerada; cordelería de pelo humano y de fibra de camélido, lienzas de algodón con lazadas para insertar anzuelo, tubo en hueso de ave; aguja de espina de cactus con orificio para pasar hilo, conchas de lapa (Fisurella sp.) amarradas con hilados de fibra de camélido (probablemente usadas como plomadas para pesca). Hay una gran cantidad de fragmentos de calabaza, algunos con orificios para unir aquellas fracturadas con hilados; lascas de cuarzo de diversas tonalidades; piedras aplanadas con pintura roja y otras con posible uso como metates y manos para molienda. En forma intermitente se presentan en este estrato costras de fogones donde el combustible principal son algas. El Estrato II es más estéril que el primero y llega hasta $40 \mathrm{~cm}$ de profundidad, presentando también intercalaciones de fogones. Hay fauna marina y terrestre similar al Estrato I. Entre los restos culturales, destaca un fragmento de cerámica café gris alisada con borde desgastado en bisel con probable reutilización funcional como pala, plumas teñidas de rojo, un "chope" de piedra aguzado y lascas de cuarzo de diversas tonalidades. Para este estrato se cuenta con una datación radiocarbónica de 2575 $\pm 90 \mathrm{AP}$ (Geochron Laboratories, Muestra GX-22435; Moragas 1997 Ms-a).

Patache P. Basural plano contiguo a un afloramiento rocoso que provee sombra y protección. Se detectaron dos estratos principales separados por un grueso fogón compacto; existiendo además pequeños lentes de ceniza intercalados dentro de cada estrato. El Estrato I registra restos malacológicos, ictiológicos, huesos de mamíferos y de aves marinas, abundante cantidad de bulbos de "argentinas", espinas de cactus y ramitas. Entre los registros culturales destaca la cordelería de fibra vegetal de diversos grosores, trozos de bolsa anillada de doble torsión de fibra vegetal gruesa, cordelería de fibra de camélido de colores naturales y teñidos. Hay varios anzuelos de cactus y una aguja del mismo material con orificio para pasar el hilo. También una punta lanceolada con aletas y una hoja de cuchillo en cuarzo blanco. El Estrato II es más compacto y estéril que el anterior y presenta alta cantidad de moluscos, espinas de cactus, bulbos de "argentinas" y totora. Entre los restos 


\begin{tabular}{|c|c|c|c|c|c|}
\hline Sitio & $\mathrm{N}^{\mathrm{o}}$ recintos & $\begin{array}{l}\text { Superficie construida } \\
\qquad\left(\mathbf{m}^{2}\right)\end{array}$ & $\begin{array}{c}\text { Superficie asentamiento } \\
\text { (ha) }\end{array}$ & $\begin{array}{l}\text { Densidad } \\
\text { (recinto/ha) }\end{array}$ & $\begin{array}{c}\text { Factor ocupación de } \\
\text { suelo (\%) }\end{array}$ \\
\hline Pisagua $\mathrm{N}$ & 25 & 432,21 & 0,090 & 277,78 & 48,02 \\
\hline Los Verdes & 1 & 12,25 & s/ref. & s/ref. & s/ref. \\
\hline Sarmenia & 8 & 66,68 & 0,294 & 27,21 & 2,26 \\
\hline Pabellón de Pica & 1 & 87,55 & s/ref. & s/ref. & s/ref. \\
\hline Chomache & 5 & 63,07 & 0,021 & 238,10 & 30,03 \\
\hline Punta Blanca & 8 & 78,04 & 0,125 & 64,00 & 6,21 \\
\hline Caleta Huelén Alto & 159 & 1299,82 & 1,354 & 117,43 & 0,95 \\
\hline Caleta Huelén 42 & 30 & 70,79 & 0,328 & 91,46 & 4,29 \\
\hline
\end{tabular}

Tabla 2. Densidad de recintos y Factor de Ocupación de Suelo (FOS) por sitio.

culturales hay anzuelos de cactus, desconchadores de costillas de lobo marino, dos cuentas de turquesa, tajadores en rodados, fragmentos de calabaza, lienzas de algodón, y cordelería de fibra de camélido natural y artificial. De este estrato se tomó una muestra para datación radiocarbónica, cuyo resultado fue el más temprano para los sitios formativos del área: $3210 \pm 45 \mathrm{AP}$ (Geochron Laboratories, Muestra GX-22436; Moragas 1997 Ms-a).

De acuerdo al conjunto de investigaciones realizadas en Punta Patache se pudo establecer que ningún yacimiento contiene la secuencia total. Por el contrario, cada sitio generalmente representa un solo episodio ocupacional, siendo escasas las excepciones con dos períodos, donde el abandono temporal del sitio está claramente constatado. Sin duda, llama la atención la gran cantidad de sitios asignables al período Formativo en la localidad de Patache ya que de 20 sitios estudiados hasta el momento, contamos con cinco fechas que confirman su asignación cultural a este período y existen al menos seis sitios más en el sector, que aunque no cuentan con dataciones absolutas, pueden incluirse en él, de acuerdo a sus contextos culturales y patrón de asentamiento. Según las investigaciones de Moragas (1996 Ms, 1997 Ms-a), es igualmente llamativa la baja frecuencia de sitios que representan períodos previos o posteriores al Formativo, lo cual puede significar que entre 1260 AC y 325 DC (ver Tabla 1) las condiciones del sector pudieron ser muy favorables $y$ atractivas para estas comunidades, al igual que la playa vecina de Cáñamo, generando una intensa, móvil y a la vez dispersa ocupación de la localidad. En varios de los
20 yacimientos excavados y a lo largo de toda la secuencia cronológica representada por los sitios del sector, se detectaron evidencias dispersas de pequeñas estructuras circulares de diámetros de 1,5 a 2,5 m, confeccionadas con piedras de 0,3 a o,4 m de largo. En general, son estructuras de muros simples, sin argamasa que indican espacios de dormitorio y cocina; en ciertos casos, bajo los pisos habitacionales, se hallan tumbas.

Cabe poca duda de que los grupos que habitaron el área en forma efímera o algo más estable mantenían una economía mayoritariamente especializada en la explotación marítima. El lobo marino y el pelícano parecen haber sido básicos para su sustento atendiendo al registro frecuente de focos de faenamiento y cocina de estas especies. La recolección de moluscos y la pesca también constituyó parte importante de sus actividades e igualmente la recolección de bulbos alimenticios de la familia Tecofiléacea (Zephira elegans o "argentinas") en los cerros y oasis de niebla ubicados en la cordillera de la Costa (Moragas $1977 \mathrm{Ms}^{10}$, $1996 \mathrm{Ms}$ ), así como maderas y espinas de cactáceas. Por otra parte, y aunque en menor frecuencia, se advierte el manejo de recursos complementarios provenientes de valles y oasis interiores. El contacto con comunidades agropastoriles se evidencia a través de la incorporación de cultígenos como calabaza y maíz, de la textilería de fibra de camélido y de la invención/adopción de la tecnología cerámica. Aunque uno de los sitios

\footnotetext{
${ }^{10}$ Identificación de Mélica Muñoz, del Museo Nacional de Historia Natural.
} 


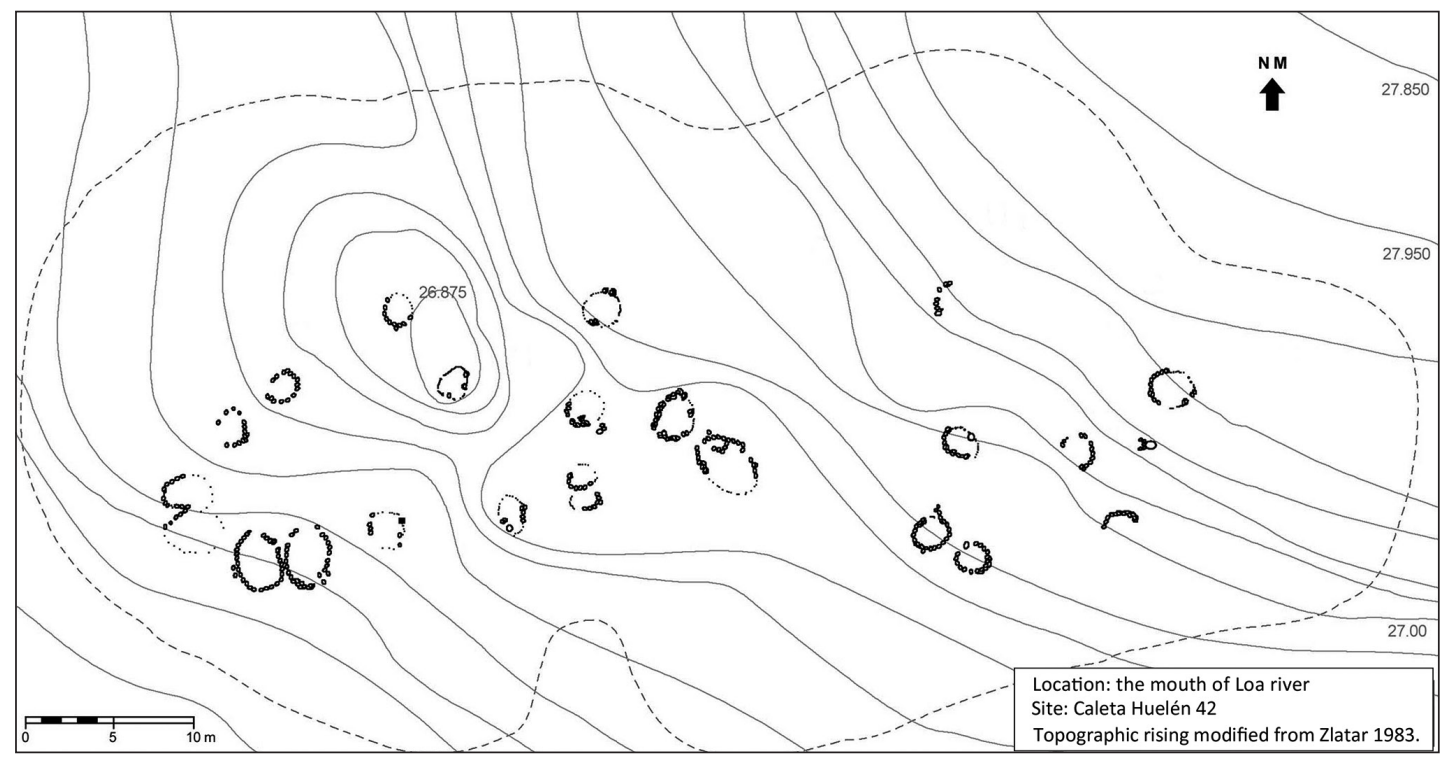

Figura 3. Levantamiento topográfico de Caleta Huelén 42.

contiene un trozo de cobre laminado (placa), no se registraron instrumentos de metal. El algodón está presente desde muy temprano en la costa y es probable que haya crecido en forma natural cerca de las aguadas u otras zonas con mayores recursos hídricos (Moragas 1977 Ms).

\section{Asentamientos y arquitectura costera}

Caleta Huelén 42 (CaH-42). Este asentamiento, localizado en la desembocadura del río Loa a $920 \mathrm{~m}$ del litoral (UTM: 7630354 N / $391031 \mathrm{E}$ ), ha sido descrito como una aldea dispersa, un caserío emergente o campamento semiestable en una fase de transición hacia la sedentarización (Zlatar 1983) (Tabla 2). Posee 30 estructuras de forma circular, semisubterráneas y subterráneas, junto a sectores de basurales asociados (Núñez 1971, 1976). Se trata de un conjunto de recintos aglomerados de manera celular, dispuestos alrededor de un patio central hacia donde se orientan los vanos y donde se pudieron realizar las actividades comunales. La cronología del sitio indicaría un momento inicial de ocupación datado en

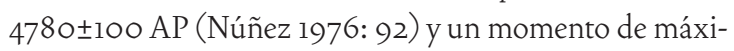
mo desarrollo fechado en 3780 £90 AP (Núñez 1976: 93).

Los recintos semisubterráneos fueron edificados con grandes piedras verticales y otras más pequeñas dispues- tas en forma horizontal, con hiladas simples y en algunos casos de doble corrida, unidas con argamasa de ceniza de algas, basura y arena conchífera probablemente preparada con agua de mar (Zlatar 1983: 22-24). Al interior de tres estructuras sería posible distinguir pequeñas subestructuras adosadas al modo de depósitos o bodegas. En ellas se observan enterramientos bajo pisos sellados preparados con argamasa, los cuales consisten en esqueletos dispuestos en forma horizontal sobre esteras, con su ajuar funerario, registrándose cráneos sin cuerpos y esqueletos sin cráneos. En las excavaciones, se constató que hubo un gran número de cuerpos bajo los recintos 1 y 6 , con 12 y 15 individuos respectivamente, y en menor cantidad en el resto. La autora también describe recintos subterráneos de forma similar, pero en solo uno de ellos se pudo confirmar la presencia de restos humanos (Zlatar 1983). La excavación de los recintos permitió determinar que fueron construidos sobre el piso mismo del conchal, con muros de piedras que utilizan elementos más pequeños y argamasa en menor proporción. En dos estructuras se constató el uso de morteros reutilizados y abundantes maderos de cactus que posiblemente sostuvieron toldos de cueros de lobos marinos.

Tomando en consideración lo anterior, el año 2005 realizamos el registro arquitectónico de 15 estructuras de 


\begin{tabular}{|c|c|c|c|c|c|c|c|c|c|c|c|c|c|c|}
\hline $\begin{array}{l}\text { Caleta Huelén } \\
\text { Alto }\end{array}$ & $\begin{array}{c}0-5,1 \\
\mathrm{~m}^{2}\end{array}$ & $\%$ & $\begin{array}{c}5-10,1 \\
\mathrm{~m}^{2}\end{array}$ & $\%$ & $\begin{array}{c}10-20,1 \\
\mathrm{~m}^{2}\end{array}$ & $\%$ & $\begin{array}{c}20-40,1 \\
\mathrm{~m}^{2}\end{array}$ & $\%$ & $\begin{array}{c}40-60,1 \\
m^{2}\end{array}$ & $\%$ & $\begin{array}{c}>60,1 \\
\mathrm{~m}^{2}\end{array}$ & $\%$ & Total & $\begin{array}{c}\text { Superficie } \\
\mathbf{m}^{2}\end{array}$ \\
\hline Rectangular & 3 & 3,80 & 4 & 9,30 & 2 & 7,41 & & & & & & & 9 & 64,12 \\
\hline Subrectangular & 15 & 18,99 & 17 & 39,53 & 13 & 48,15 & 1 & 16,67 & & & & & 46 & 379,49 \\
\hline Cuadrangular & 3 & 3,80 & 1 & 2,33 & & & 1 & 16,67 & & & & & 5 & 42,65 \\
\hline Subcuadrangular & 1 & 1,27 & 1 & 2,33 & & & & & & & & & 2 & 10,07 \\
\hline Circular & 10 & 12,66 & & & 1 & 3,70 & & & & & & & 11 & 29,91 \\
\hline Subcircular & 14 & 17,72 & 3 & 6,98 & & & & & & & & & 17 & 57,43 \\
\hline Elipsoidal & 1 & 1,27 & & & 1 & 3,70 & & & & & & & 2 & 15,43 \\
\hline Ovoidal & 5 & 6,33 & 3 & 6,98 & 1 & 3,70 & & & & & & & 9 & 42,91 \\
\hline Trapezoidal & & & 1 & 2,33 & & & & & & & & & 1 & 7,28 \\
\hline Triangular & 2 & 2,53 & & & & & & & & & & & 2 & 2,9 \\
\hline Irregular & 24 & 30,38 & 12 & 27,91 & 7 & 25,93 & 4 & 66,67 & 3 & 100,0 & 1 & 100,00 & 51 & 613,69 \\
\hline N/o & 1 & 1,27 & 1 & 2,33 & 2 & 7,41 & & & & & & & 4 & 33,96 \\
\hline Total & 79 & 100,0 & 43 & 100,0 & 27 & 100,0 & 6 & 100,0 & 3 & 100,0 & 1 & 100,0 & 159 & \\
\hline Superficie $\mathbf{m}^{2}$ & 189,89 & & 303,02 & & 383,69 & & 175,22 & & 151,72 & & 96,30 & & & 1299,84 \\
\hline
\end{tabular}

Tabla 3. Caleta Huelén Alto. Distribución de formas de plantas según rangos de tamaño.

Caleta Huelén 42 (Adán y Urbina 2005 Ms), es decir, alrededor del 50\% de las registradas previamente (Zlatar 1983). El asentamiento se ubica a 26 m.s.n.m. sobre una terraza de abrasión marina al norte del río Loa. Se percibe como un basural conchífero tumular con estructuras expuestas mediante excavaciones arqueológicas (Figura 3). Dicho túmulo también se compone de material orgánico, vegetal (totora o juncos), huesos de pescado, mamíferos marinos y terrestres, y restos malacológicos. En superficie se aprecian algunos fragmentos cerámicos muy erosionados, siendo posible distinguir dos sectores segregados por un espacio no excavado (Zlatar 1983: 23, lám. 1). En el sector oeste registramos 10 estructuras y en el sector este, cinco. Según Zlatar habrían 30 estructuras sobre $3820 \mathrm{~m}^{2}$, por lo que calculamos para el asentamiento una densidad constructiva de 91.46 recintos por hectárea (ver Tabla 2), cuestión que coincide con la observación de la autora, según la cual, bajo el túmulo "el sitio debe estar conformado por unas 100 viviendas" (Zlatar 1983: 22). En base a las 15 estructuras registradas en el año 2005 se estimó una superficie constructiva total del sitio de $141,58 \mathrm{~m}^{2}$, considerando el 50\% de ellas $(70,79$ $\mathrm{m}^{2}$; ver Tabla 2). Cruzando estos valores, el área utilizada por las construcciones habría alcanzado 4,29\% de la superficie total del asentamiento (Tabla 3).
La clasificación de las formas de las estructuras de Caleta Huelén 42 indica el dominio de plantas ovoidales (40\%), subcirculares $(33,3 \%)$ y elipsoidales (10\%) (Tabla 4$)$. Todas ellas presentan un muro continuo curvo, edificado con lajas verticales o pilares enterrados en el depósito de conchas y atravesando el piso de argamasa que sellaba los cuerpos. La clasificación de los tamaños de las estructuras indican que los habitantes de Caleta Huelén 42 utilizaron plantas cuyas superficies internas oscilan entre 2,4 y $8,4 \mathrm{~m}^{2}$. En su mayoría corresponden a estructuras muy pequeñas ubicadas bajo los $5 \mathrm{~m}^{2}$, que alcanzan $66,6 \%$ de representación, seguidas por plantas que abarcan de 5,1 a $10 \mathrm{~m}^{2}$, con el 33,3\% del total registrado $(\mathrm{n}=15)$ (Tabla 5). Mientras los largos oscilan entre 1,6 y 4,2 m, los anchos lo hacen entre 1,5 y $2,25 \mathrm{~m}$.

Según nuestro registro, los paramentos de Caleta Huelén 42 muestran una mayoría de muros simples, aplomados y aparejos sedimentarios (Tabla 6), aunque identificamos en menor cantidad muros levemente desaplomados al interior y, según indica Zlatar (1983), en las excavaciones también se registraron muros de doble hilera. Los materiales constructivos fueron piedras de gran tamaño (alto: 0,55 m, ancho: 0,36 m, espesor: 0,1 m) utilizadas como pilares fundacionales $y$, sobre éstas, hasta cuatro hiladas 


\begin{tabular}{|c|c|c|c|c|c|c|c|c|c|c|c|c|c|c|}
\hline$\stackrel{8}{\sharp}$ & 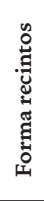 & 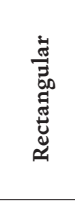 & 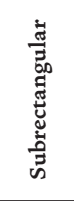 & 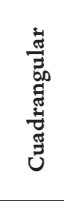 & 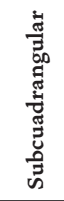 & 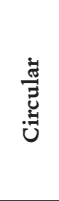 & 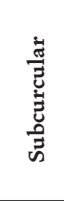 & 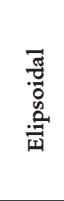 & $\begin{array}{l}\bar{\pi} \\
\frac{\pi}{0} \\
0 \\
0\end{array}$ & 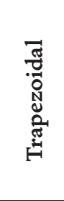 & 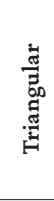 & 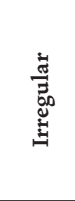 & $\stackrel{\circ}{a}$ & 胥 \\
\hline \multirow{2}{*}{ Pisagua N } & $\mathrm{n}$ & 6 & & 7 & 3 & & 2 & & 1 & 6 & & & & 25 \\
\hline & $\%$ & 24,0 & & 28,0 & 12,0 & & 8,0 & & 4,0 & 24,0 & & & & 100,0 \\
\hline \multirow{2}{*}{ Los Verdes } & $\mathrm{n}$ & 1 & & & & & & & & & & & & 1 \\
\hline & $\%$ & 100,0 & & & & & & & & & & & & 100,0 \\
\hline \multirow{2}{*}{ Sarmenia } & $\mathrm{n}$ & 3 & 1 & 1 & & 2 & & & & & & 1 & & 8 \\
\hline & $\%$ & 37,50 & 12,50 & 12,50 & & 25,0 & & & & & & 12,50 & & 100,0 \\
\hline \multirow{2}{*}{$\begin{array}{l}\text { Pabellón de } \\
\text { Pica }\end{array}$} & $\mathrm{n}$ & & & & & & & & 1 & & & & & 1 \\
\hline & $\%$ & & & & & & & & 100,0 & & & & & 100,0 \\
\hline \multirow{2}{*}{ Chomache } & $\mathrm{n}$ & 1 & 3 & & 1 & & & & & & & & & 5 \\
\hline & $\%$ & 20,0 & 60,0 & & 20,0 & & & & & & & & & 100,0 \\
\hline \multirow{2}{*}{ Punta Blanca } & $\mathrm{n}$ & & 5 & & & & & & & & & 3 & & 8 \\
\hline & $\%$ & & 62,50 & & & & & & & & & 37,50 & & 100,0 \\
\hline \multirow{2}{*}{$\begin{array}{l}\text { Caleta Huelén } \\
\text { Alto }\end{array}$} & $\mathrm{n}$ & 9 & 46 & 5 & 2 & 11 & 17 & 2 & 9 & 1 & 2 & 51 & 4 & 159 \\
\hline & $\%$ & 5,66 & 28,93 & 3,14 & 1,25 & 6,91 & 10,69 & 1,25 & 5,66 & 0,62 & 1,25 & 30,07 & 2,51 & 100,0 \\
\hline \multirow{2}{*}{$\begin{array}{l}\text { Caleta Huelén } \\
42\end{array}$} & $\mathrm{n}$ & & & & & & 5,0 & 1,0 & 9,0 & & & & & 15 \\
\hline & $\%$ & & & & & & 33,33 & 6,66 & 40,0 & & & & & 100,0 \\
\hline
\end{tabular}

Tabla 4. Distribución de formas de plantas arquitectónicas por sitio.

\begin{tabular}{|c|c|c|c|c|c|c|c|c|c|}
\hline 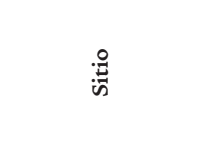 & 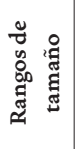 & 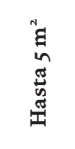 & $\begin{array}{l}{ }^{2} \\
0 \\
- \\
1 \\
7 \\
i n\end{array}$ & $\begin{array}{l}n \\
1 \\
0 \\
N \\
1 \\
7 \\
0 \\
0\end{array}$ & $\begin{array}{l}\text { a } \\
0 \\
+ \\
1 \\
7 \\
0 \\
\text { N }\end{array}$ & $\begin{array}{l}\text { İ } \\
0 \\
0 \\
1 \\
1 \\
0 \\
0 \\
+\end{array}$ & 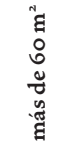 & $\stackrel{\circ}{a}$ & 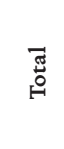 \\
\hline \multirow{2}{*}{ Pisagua N } & $\mathrm{n}$ & 3 & 4 & 6 & 10 & 1 & & 1 & 25 \\
\hline & $\%$ & 12,0 & 16,0 & 24,0 & 40,0 & 4,0 & & 4,0 & 100,0 \\
\hline \multirow{2}{*}{ Los Verdes } & $\mathrm{n}$ & & & 1 & & & & & 1 \\
\hline & $\%$ & & & 100,0 & & & & & 100,0 \\
\hline \multirow{2}{*}{ Sarmenia } & $\mathrm{n}$ & 4 & 2 & 2 & & & & & 8 \\
\hline & $\%$ & 50,0 & 25,0 & 25,0 & & & & & 100,0 \\
\hline \multirow{2}{*}{ Pabellón de Pica } & $\mathrm{n}$ & & & & & & 1 & & 1 \\
\hline & $\%$ & & & & & & 100,0 & & 100,0 \\
\hline \multirow{2}{*}{ Chomache } & $\mathrm{n}$ & & 4 & 1 & & & & & 5 \\
\hline & $\%$ & & 80,0 & 20,0 & & & & & 100,0 \\
\hline \multirow{2}{*}{ Punta Blanca } & $\mathrm{n}$ & 2 & 3 & 3 & & & & & 8 \\
\hline & $\%$ & 25,0 & 37,50 & 37,50 & & & & & 100,0 \\
\hline \multirow{2}{*}{ Caleta Huelén Alto } & $\mathrm{n}$ & 79 & 43 & 27 & 6 & 3 & 1 & & 159 \\
\hline & $\%$ & 49,68 & 27,04 & 16,98 & 3,77 & 1,88 & 0,62 & & 100,0 \\
\hline \multirow{2}{*}{ Caleta Huelén 42} & $\mathrm{n}$ & 10 & 5 & & & & & & 15 \\
\hline & $\%$ & 66,66 & 33,33 & & & & & & 100,0 \\
\hline
\end{tabular}

Tabla 5. Distribución de rangos de tamaño por sitio. 


\begin{tabular}{|c|c|c|c|c|c|c|c|c|c|}
\hline 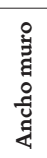 & 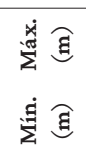 & 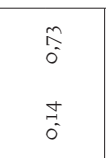 & $\begin{array}{l}0_{0}^{t} \\
0 \\
0\end{array}$ & \begin{tabular}{l}
$\hat{0}$ \\
0 \\
0 \\
\multirow{0}{0}{} \\
0
\end{tabular} & $\begin{array}{l}\text { nq } \\
0 \\
0 \\
0 \\
0 \\
0\end{array}$ & $\begin{array}{l}n \\
\hat{0} \\
0 \\
n \\
0\end{array}$ & $\begin{array}{l}0 \\
0 \\
\hat{0}\end{array}$ & $\begin{array}{l}\stackrel{3}{=} \\
\overrightarrow{0}\end{array}$ & $\begin{array}{l}0 \\
0 \\
\cong \\
0\end{array}$ \\
\hline & 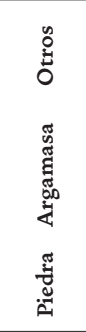 & 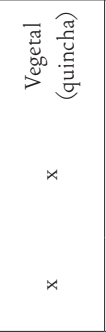 & $\star$ & 怘 & ${ }^{\star}$ & 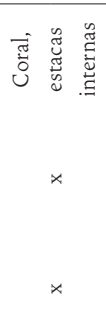 & $\star$ & $\star$ & 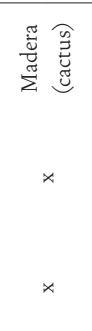 \\
\hline 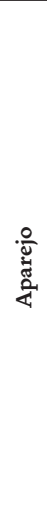 & 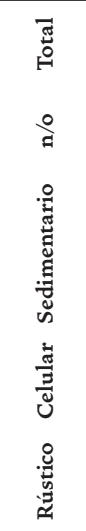 & \begin{tabular}{cc} 
& 0 \\
$\circ$ & 0 \\
\hdashline & 0 \\
& 0 \\
$\vec{N}$ & 0 \\
& $\stackrel{\vec{N}}{N}$
\end{tabular} & $\begin{array}{r} \\
+\quad 0 \\
0 \\
0\end{array}$ & 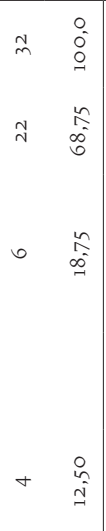 & 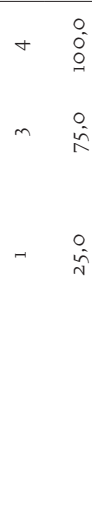 & 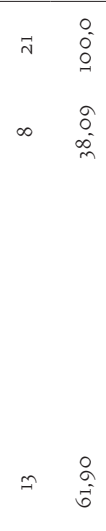 & $\begin{array}{l}m \\
m \quad \begin{array}{l}N \\
\dot{\sigma}\end{array} \\
\end{array}$ & 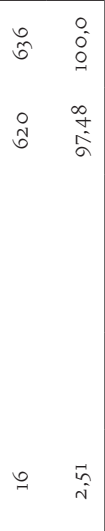 & 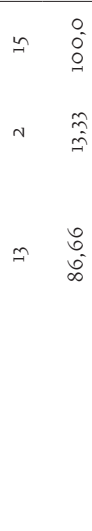 \\
\hline 苞 & 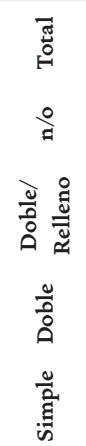 & 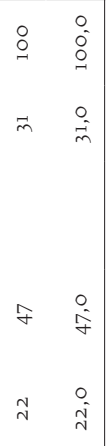 & 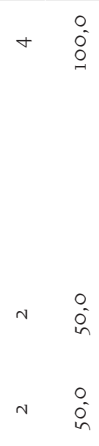 & 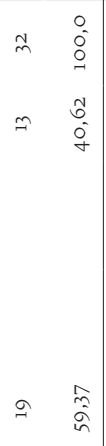 & 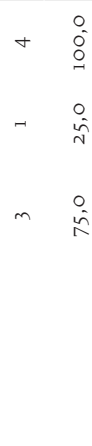 & 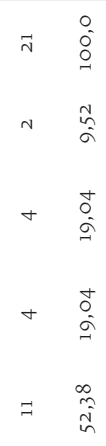 & 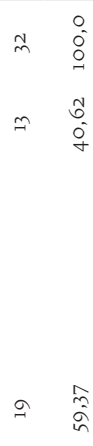 & 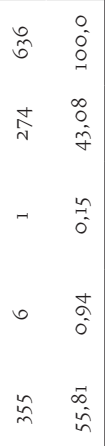 & $\because \begin{array}{l}0 \\
\vdots \\
0\end{array}$ \\
\hline & & 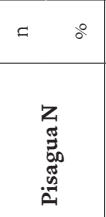 & 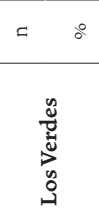 & 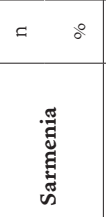 & 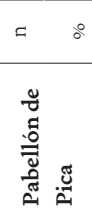 & 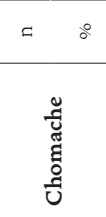 & 恚 & 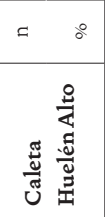 & نั \\
\hline
\end{tabular}

Tabla 6. Características de los paramentos por sitio.

de lajas planas, guijarros medianos y pequeños dispuestos horizontalmente en la sección superior del muro; todos unidos con argamasa elaborada con ceniza y material orgánico. La argamasa parece haber sido aplicada en dos tratamientos, una en los paramentos y otra sobre la últi- ma hilada de piedras acostadas, unos 15 a $20 \mathrm{~cm}$ hacia la superficie. Un rasgo definitorio del asentamiento es el uso de pilares y algunas estructuras los tienen apoyados sobre la roca madre. Al estar enterrados, los pilares se soportaron sobre el corte en el terreno o, en el caso de edificarse 


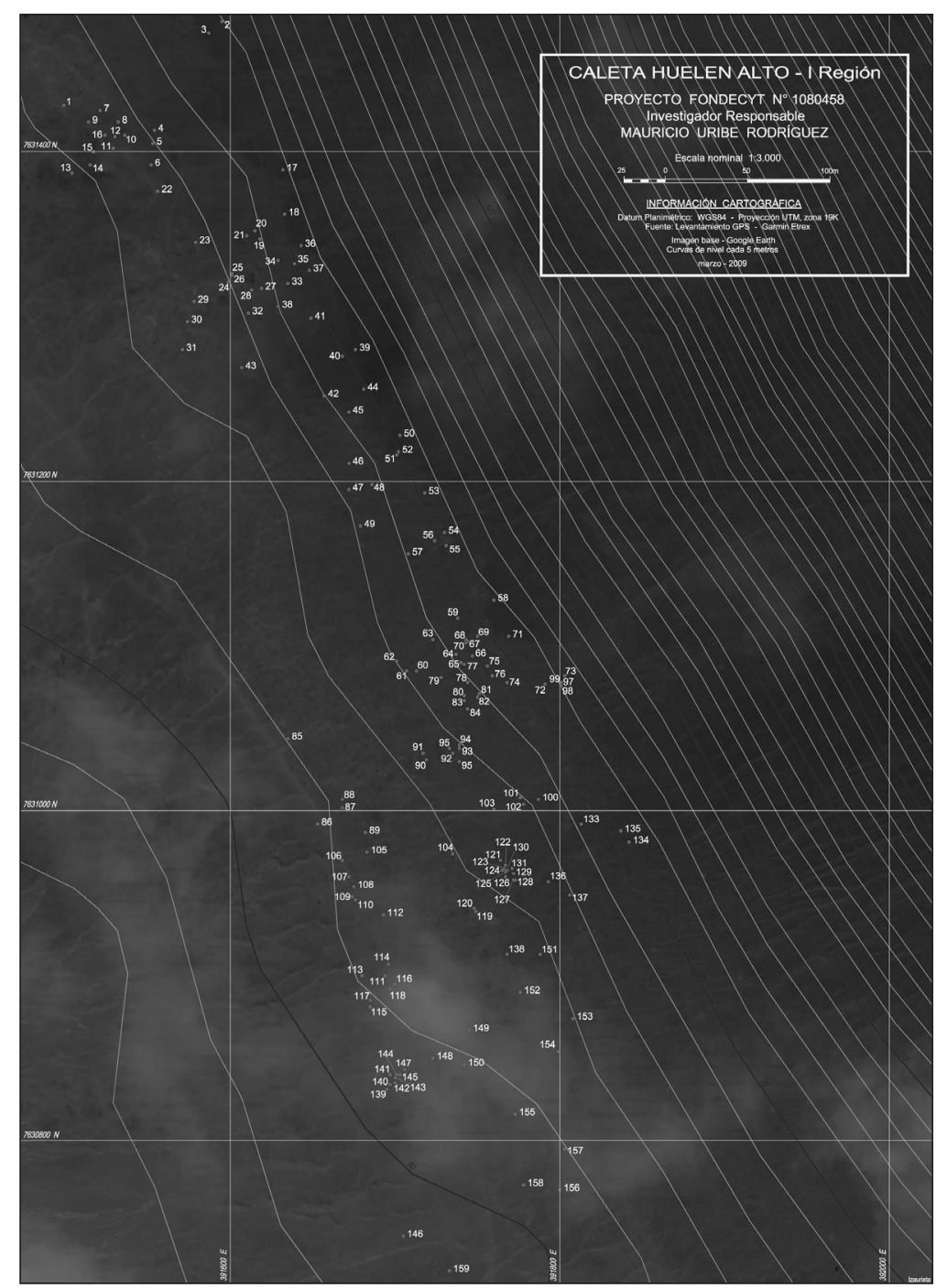

Figura 4. Levantamiento ortofotográfico de Caleta Huelén Alto.

contiguamente a otro recinto, constituían dos muros simples apoyados o un "falso" doble muro de piedras. Una estructura también presenta huesos de cetáceo en los muros. El ancho de éstos oscila entre 0,12 y 0,9 m, mientras la altura lo hace entre 0,35 y 0,9 m. De las 15 estructuras expuestas por las excavaciones, seis presentan un vano de acceso o puerta. Tres de ellas son de forma rectangular y conservan jambas a ambos costados, elaboradas con pilares similares a aquellos que conforman la primera hilada de los muros. En un caso se aprecia un alféizar elaborado en argamasa, que parece un escalón para entrar. El ancho de las entradas oscila entre 0,32 y 0,47 m, mientras el alto máximo de una de las puertas es de 0,56 m. Los seis vanos registrados se orientan al norte, con variaciones entre $308^{\circ} \mathrm{NO}$ y $20^{\circ} \mathrm{NE}$.

Caleta Huelén Alto. Es un asentamiento disperso ubicado a $800 \mathrm{~m}$ al NE de Caleta Huelén 42, entre la terraza marina y la cordillera de la Costa (65 m.s.n.m.) y a 1,8 km de la desembocadura del río Loa (UTM: 7631106 N / 391750 E; Figura 4). No posee referencias en la literatura arqueológica. Se estructura en dos sectores: el sector norte está compuesto de los conjuntos A (E.1 a 16) y B (E.17 a 29). Ambos conjuntos corresponden a estructuras dispersas 
organizadas en torno a afloramientos rocosos de altura moderada (>7 m). A continuación del conjunto B, definimos el sector sur compuesto por distintas clases de edificaciones, entre ellas, recintos adosados a afloramientos rocosos menores, parapetos semicirculares, conglomerados de estructuras, estructuras dispersas, inclusive sobre la pendiente y sobre terrenos aterrazados artificialmente. En este sector se han recolectado en superficie placas de malaquita y material calcáreo, así como cuentas y restos de collares similares a aquellos recuperados en las tumbas de los cementerios formativos Quillagua 67 y Quillagua 89 (Carrasco 2002).

Llama la atención la presencia de sectores planos despejados de planta cuadrada y rectangular, sin muros laterales, y con mineral de cobre triturado concentrado reiteradamente en el costado oeste que enfrenta al mar. Sus largos oscilan entre 1,94 y 3,6 m, mientras sus anchos lo hacen entre 1,7 y 2,8 m. También se registran áreas cuya funcionalidad desconocemos, donde se observan muchos desechos de talla de bloques de granito, que pueden alcanzar dimensiones considerables (14,2 x $7 \mathrm{~m}$ ). Una tercera clase de espacios sin definición arquitectónica clara corresponde a sectores emplazados sobre y entre bajadas naturales de agua (¿lluvias estivales?) que, al parecer corresponden a pequeñas terrazas de cultivo $y$, en sectores con menor pendiente, cuadros alineados delimitados por hileras simples de piedras pequeñas dispuestas en forma discontinua sobre la superficie.

El asentamiento se compone de 159 estructuras distribuidas sobre 13,54 ha, emplazadas en el plano de la terraza marina y en parte de la pendiente inferior de la cordillera de la Costa, abarcando 775 m en dirección N-S y 185 m en dirección E-O. La inversión arquitectónica es notable para los estándares costeros, con una superficie construida que alcanza $1299 \mathrm{~m}^{2}$ para todo el asentamiento y 229,87 $\mathrm{m}^{2}$ para el sector norte. La gran dispersión de las estructuras se ejemplifica en los 11,74 recintos por hectárea proyectados por el índice de densidad edilicia (ver Tabla 3). El Factor de Ocupación de Suelo (FOS) en relación a esta última variable no sobrepasa 0,95\% de terreno edificado. Al interior del asentamiento se distinguen senderos peatonales que lo atraviesan serpenteantes en sentido N-S; dos sobre el plano y uno sobre la pendiente que asciende de sur a norte hacia algún punto fuera del sitio, en el cerro. Una particularidad de las estructuras es la gran cantidad de desechos de mineral de cobre junto a trituradores, percutores y martillos y la casi nula presencia de desechos de moluscos, bivalvos, o restos de pescado en basurales superficiales.

El análisis de las 159 plantas arquitectónicas registradas en Caleta Huelén Alto (ver Tabla 4) indica el predominio de formas irregulares $(30,07 \%)$, subrectangulares $(28,93 \%)$ y subcirculares $(10,69 \%)$. En general, el nivel de conservación de las estructuras va de regular a malo, por lo cual se estima que la categoría irregular puede estar sobrerrepresentada. Las categorías cuadrangular y subcuadrangular, poseen una baja representación que no supera el 4,5\%, mientras estructuras con formas rectangulares y subrectangulares alcanzan $34,59 \%$. Plantas de muros curvos -circulares, subcirculares, ovoidales y elipsoidales-, agrupan 24,52\% del total. Quienes ocuparon el sitio edificaron estructuras en un amplio rango de tamaño que oscila entre 0,18 y $96,3 \mathrm{~m}^{2}$. Esas estructuras disminuyen en cantidad entre el primer rango (hasta 5 $\mathrm{m}^{2}$ ) que supera el $49 \%$, y las más grandes (sobre $60 \mathrm{~m}^{2}$ ), que solo cuentan con $0,62 \%$ de representación (ver Tabla 5). Los dos primeros rangos (hasta $10,1 \mathrm{~m}^{2}$ ) concentran más del $75 \%$ de las estructuras del sitio, que cumplirían funciones de almacenaje, posiblemente repositorios funerarios (cistas), pequeños dormitorios o parapetos, cocinas, trincheras militares y trampas subactuales, mejor conocidas en la costa como "pozo zorro". Los dos rangos donde usualmente se concentran espacios domésticos (5,1 a 20,1 $\left.\mathrm{m}^{2}\right)$ como dormitorios, cocinas y patios, alcanzan un significativo $44,02 \%$. Espacios edificados de mayor tamaño, focos de actividad de varias unidades domésticas, áreas comunales o talleres - como terraza abiertas y patios-, así como corrales para el mantenimiento de ganado, se ubican con seguridad en los tres últimos rangos por sobre los 20,1 $\mathrm{m}^{2}$, completando el 6,27\% de la muestra. Considerando el cruce de la información sobre las formas y dimensiones de las estructuras, observamos que aquellas tipo depósito o pequeños dormitorios ubicados en el primer rango de tamaño (hasta $5 \mathrm{~m}^{2}$ ), utilizan preferentemente muros curvos alcanzando en conjunto $37,98 \%$; mientras que las rectangulares, cuadrangulares y sus derivadas no superan el 28\% (ver Tabla 3). En el rango siguiente $\left(5,1\right.$ a 10,1 $\left.\mathrm{m}^{2}\right)$ esta situación se revierte, observándose la selección de plantas con esquinas en ángulo $(53,49 \%)$ y dentro de ellas estructuras rectangulares y subrectangulares $(48,83 \%)$. En cambio, las estructuras 


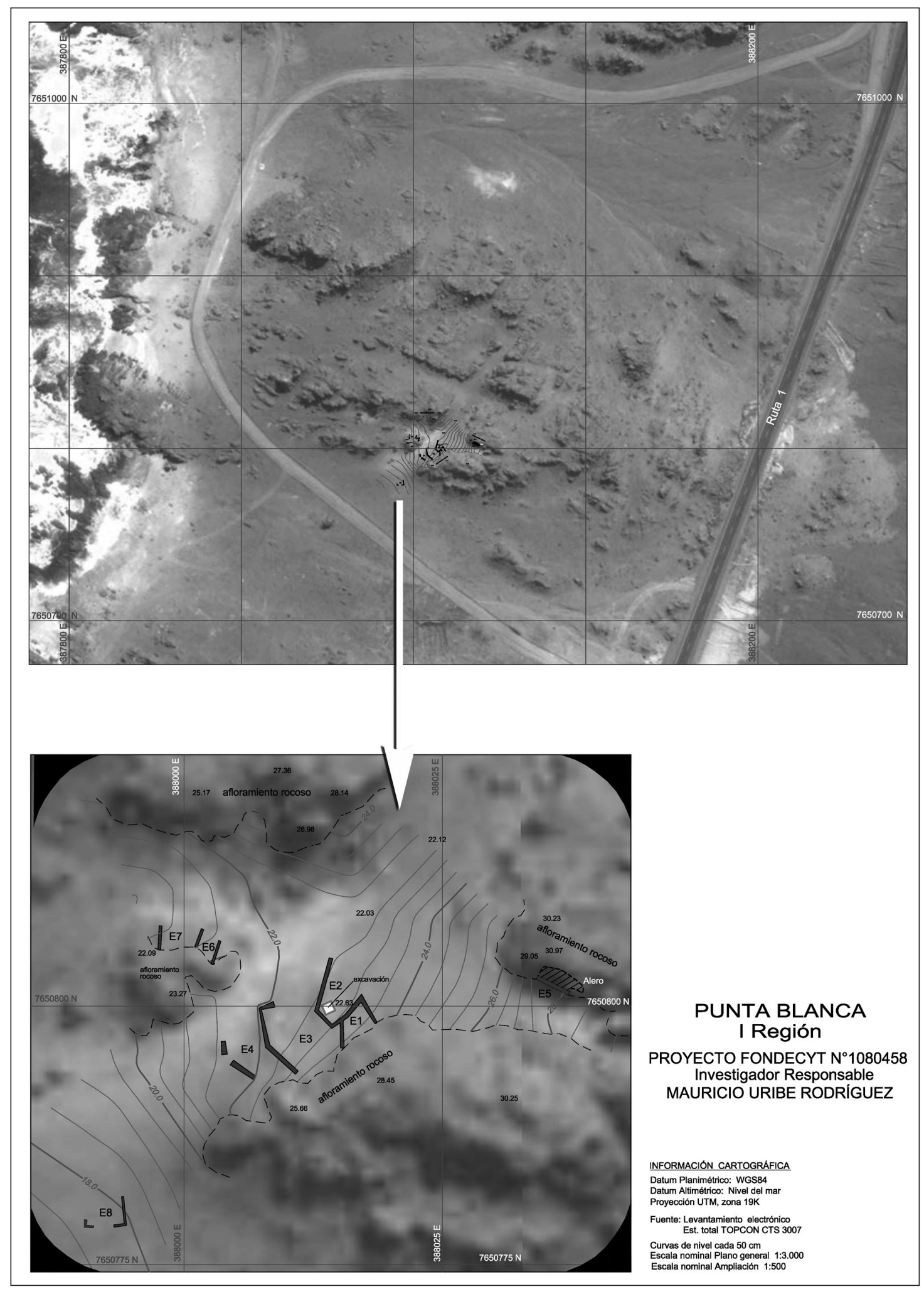

Figura 5. Levantamiento topográfico de Punta Blanca. 
con muros curvos descienden abruptamente bajo $14 \%$. Dicha situación se mantiene en el rango siguiente (10,1 a $20,1 \mathrm{~m}^{2}$ ) donde estructuras rectangulares y subrectangulares alcanzan un 55,56\%; en cambio, espacios con paredes curvas llegan a 11,1\%. Lo anterior es indicador del uso de dos tipos de unidades domésticas presentes en el asentamiento.

Respecto a los paramentos de Caleta Huelén, hemos incluido en el análisis 636 muros registrados (cuatro muros por estructura) (ver Tabla 6), observando el uso predominante de clastos angulosos locales de riolita que provienen del acarreo o desmonte de bloques desde el farellón costero. Los muros son simples $(55,81 \%)$ de aparejos rústicos y mayormente aplomados. La altura de los muros no supera 1,2 $\mathrm{m}$, en tanto los anchos oscilan entre 0,1 y 1,5 m, coincidiendo en algunos casos con el uso de bloques rocosos de gran tamaño para el apoyo y soporte de los paramentos.

Punta Blanca. A $21 \mathrm{~km}$ al norte de la desembocadura del río Loa, registramos el sitio Punta Blanca, que hasta el momento no contaba con antecedentes arqueológicos (UTM: 7650811 N / 388018 E; Figura 5). Corresponde a un asentamiento compuesto de ocho estructuras dispersas entre afloramientos rocosos y sobre un pequeño conchal ubicado a 1,8 km del litoral, a 22 m.s.n.m. El perímetro del asentamiento ocupa una superficie de $1255 \mathrm{~m}^{2}(53,2 \times 23,6 \mathrm{~m})$, entre afloramientos rocosos se incluye un basural conchífero donde también se aprecian restos de cerámica y estructuras de piedra. Estos valores proyectan una densidad edilicia moderada de 64 recintos por hectárea (ver Tabla 2). La superficie edificada del asentamiento es de 78,04 $\mathrm{m}^{2}$, por lo tanto, el porcentaje de superficie utilizada con fines constructivos alcanza un indice FOS de 6,21\%.

El asentamiento muestra una clara orientación hacia los recursos del litoral. Los recintos se encuentran dispuestos en dos conglomerados junto a dos afloramientos de alturas moderadas ( 1,5 a $7 \mathrm{~m}$ ), además de una estructura ubicada bajo un pequeño alero rocoso y otra en un sector plano más bajo y distante. Las estructuras presentan plantas subrectangulares $(62,5 \%)$ e irregulares $(37,5 \%)$ en menor proporción (ver Tabla 4). Los tamaños oscilan entre 3,6 y $17,15 \mathrm{~m}^{2}$, concentrándose un $37,5 \%$ en los rangos pequeños $\left(5,1-10,1 \mathrm{~m}^{2}\right)$ y en igual proporción en el primer rango de espacios medianos $\left(10,1-20,1 \mathrm{~m}^{2}\right)$; ambos son indicadores de espacios domésticos. Un $25 \%$ de las estructuras son construcciones muy pequeñas con menos de $5 \mathrm{~m}^{2}$, posiblemente destinadas a almacenaje, cocina o pequeños dormitorios (ver Tabla 5). Los paramentos de Punta Blanca se edificaron utilizando una expeditiva técnica conocida como "pirca seca", es decir, muros construidos con bloques irregulares y angulosos sin trabajo, pero seleccionados por tamaño, dispuestos en hileras simples (59,37\%) y de aparejo rústico (59,37\%). No se utilizó mezcla adherente (como la argamasa). Los anchos de los muros abarcan entre 0,17 y $0,5 \mathrm{~m}$, en tanto las alturas no superan $0,29 \mathrm{~m}$ en el caso de los muros edificados y, 0,5 m en el de los afloramientos utilizados como parte de las estructuras.

Chomache. El asentamiento está ubicado en una pequeña saliente que se proyecta cerca de $1 \mathrm{~km}$ desde la cordillera de la Costa hacia el océano Pacífico (UTM: 7663482 N / 382641 E; Figura 6). Se encuentra $3 \mathrm{~km}$ al sur de la Aguada Punta Lobos situada en la bahía Chomache en Caleta San Marcos. Según Núñez y Varela (1967-68: 22-23) el relieve del sector se caracteriza por el desarrollo de una terraza de abrasión marina de promontorios o cerrillos de alturas que van desde 200 a 250 m.s.n.m., donde existen pequeños cursos de agua ya secos, producto de condensaciones de neblinas rasantes con vegetación natural circundante, entre los que destaca uno claramente con ocupación humana. Las ocupaciones detectadas en este sector se ubican preferentemente al sur de Punta de Lobos, debido al aprovechamiento del recurso hídrico, donde se identifican campos de basuras extendidas que alcanzan en ciertos casos $150 \mathrm{~m}$ de largo. Uno de estos asentamientos se denomina PL-1 y se trata de un depósito de basuras monticulares, similar a Cáñamo 1, con un estrato de ocupación continua asociada directamente a recursos hídricos de vertiente.

El sitio denominado Chomache se encuentra a $14 \mathrm{~km}$ al norte de Punta Blanca y a 1,8 km al sur de la actual Caleta San Marcos. Dentro de sus particularidades, se puede consignar que se encuentra a $160 \mathrm{~m}$ al S-SO de un panel rupestre (petroglifo) con figuras de aves y mamíferos marinos elaborados mediante raspado areal y camélidos pintados de rojo. El asentamiento se encuentra a 1,3 km del litoral rocoso que domina todo el contorno costero, distinguiéndose colonias de aves que forman diversas 


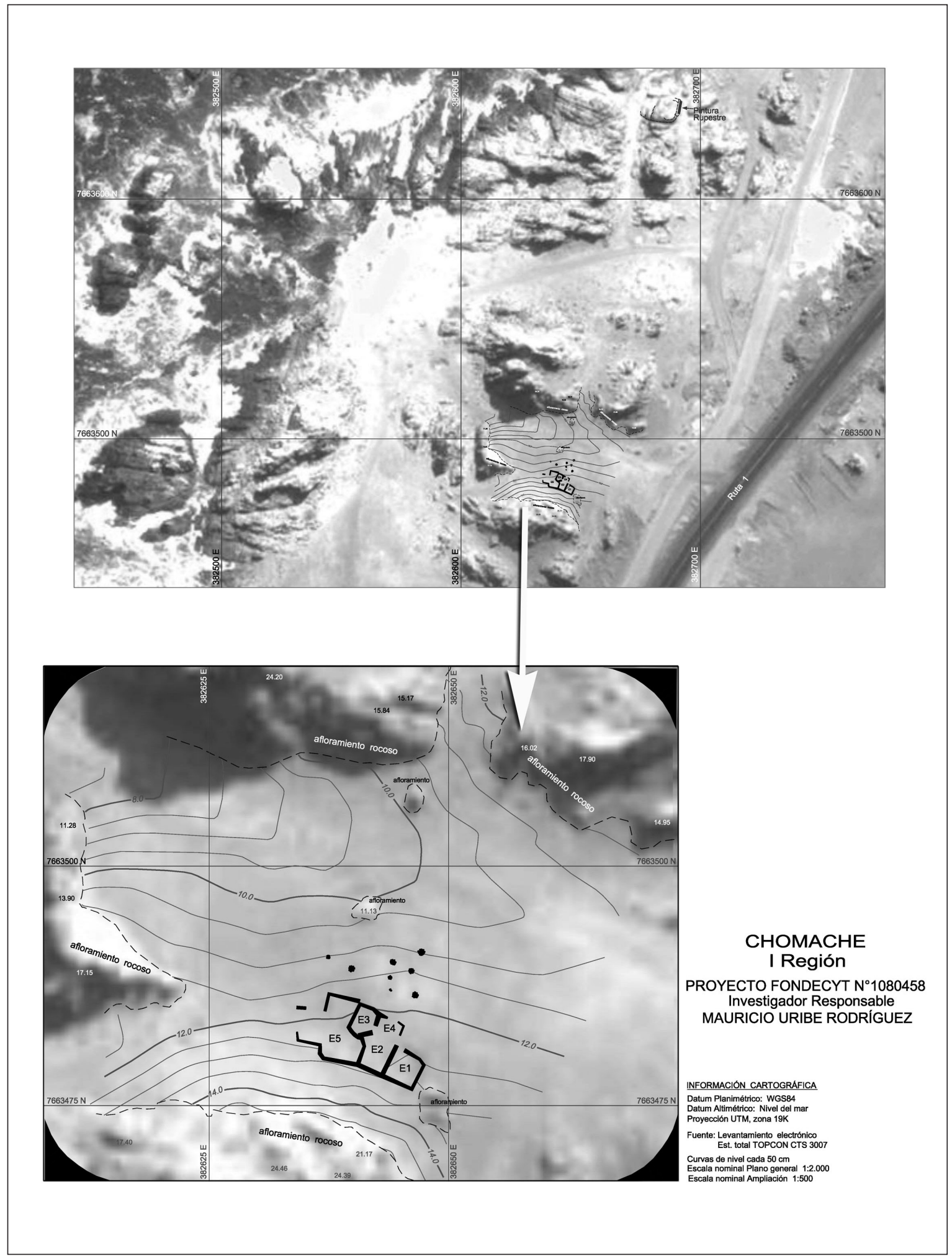

Figura 6. Levantamiento topográfico de Chomache. 
guaneras. El asentamiento se percibe como un conglomerado compacto orientado en sentido E-O, edificado a los pies de un afloramiento rocoso de $17 \mathrm{~m}$ de altura, aterrazando la superficie al menos en dos niveles artificiales escalonados. El primero de ellos es más evidente, con un muro continuo de contención de unos $15 \mathrm{~m}$ de largo que corta la pendiente en $1 \mathrm{~m}$ de profundidad y que fue subdividido mediante muros transversales apoyados, que delimitaron tres estructuras principales.

El sitio cuenta con cinco estructuras sobre una superficie de $2100 \mathrm{~m}^{2}(21 \times 10 \mathrm{~m})$, lo cual indica una alta densidad edilicia de 238,1 recintos por hectárea (ver Tabla 2). La superficie edificada alcanza $63,07 \mathrm{~m}^{2}$, lo que permite calcular un alto índice FOS de alrededor de 30,03\% de terreno destinado a las estructuras. Fuera de ellas existe bastante basura, en su mayoría restos malacológicos que constituyen un conchal extendido alrededor del conglomerado. Las formas de las estructuras son preferentemente rectangulares y subrectangulares (80\%); mientras las restantes son cuadrangulares (ver Tabla 4). Las estructuras subrectangulares presentan sus esquinas ligeramente curvadas, como se vio en la estructura 1 luego de ser excavada. Los tamaños oscilan entre 5,2 y $33,15 \mathrm{~m}^{2}$, ubicándose un $80 \%$ en el segundo rango de tamaño $\left(5-10,1 \mathrm{~m}^{2}\right)$ y la estructura restante en el siguiente rango (10,1-20,1 $\mathrm{m}^{2}$ ) (ver Tabla 5). De acuerdo a esto, Chomache constituye un asentamiento aglutinado de carácter eminentemente doméstico, donde debieron realizarse funciones de almacenaje, dormitorio, cocina y patios como áreas de actividad diaria. También debieron existir basurales, quizás amparados en los muros, tanto en el interior como en el exterior del conglomerado. Esta clase de sitios es novedosa para el período Formativo en la costa desértica de interfluvio.

Los paramentos entregan información relevante sobre los elementos constructivos del sitio (ver Tabla 6), lo que evidencia criterios técnicos y estilísticos también documentados en asentamientos más tempranos y distantes. En primer lugar, del total de paramentos registrados $(n=21)$, se detectaron mayoritariamente $\mathrm{mu}$ ros simples $(52,38 \%)$ aplomados y aparejos rústicos $(61,9 \%)$, aunque también muros dobles y dobles con relleno en igual proporción (19,04\%). La excavación de las estructuras 1 y 3 evidenció el uso de lajas enterradas verticalmente o pilares como hilada fundacional de las estructuras, cuyas medidas son $0,7 \mathrm{~m}$ de alto, $0,45 \mathrm{~m}$ de ancho y o,25 de espesor. Sobre la primera hilada de pilares se disponen horizontalmente las hiladas superiores de piedras angulosas seleccionadas por tamaño, que no llegan a constituir aparejos sedimentarios. Se registró el uso de bloques cortados de coral en el muro de contención, del mismo tamaño que las piedras, y también una pequeña estaca de madera enterrada en el piso ocupacional de la estructura I (Ajata y Méndez-Quirós 2009). El ancho de los muros en general oscila entre 0,15 y 0,6 m, y las alturas entre 0,1 y 0,97 m. En el total de los muros analizados se detectó el uso de argamasa, especialmente en el caso de los muros dobles y dobles con relleno, así como en forma abundante en el muro de contención de la terraza. La argamasa es de color ceniza blanquecina y está mezclada con restos malacológicos, carbón y gravilla.

Pabellón de Pica. Es un asentamiento detectado en una prospección sistemática (Ajata 2009 Ms) que no había sido documentado en la literatura arqueológica (UTM: 7690807 N / 381339 E; Figura 7). Se ubica a $230 \mathrm{~m}$ de la playa y 10 m.s.n.m., a $10 \mathrm{~km}$ al sur de Punta Patache y $27,3 \mathrm{~km}$ al norte de Chomache, y a $2 \mathrm{~km}$ al norte de Caleta Chanavaya que, a su vez, está próxima a una aguada activa, conocida como Pabellón de Pica, descrita como de bajo caudal y mala calidad (Niemeyer y Cereceda 1984). El asentamiento comprende una estructura semienterrada emplazada en un terreno plano y abierto de arenas finas, rodeada de restos malacológicos que, a juzgar por las intervenciones no sistemáticas ("huaqueo") en su exterior constituyen un conchal estratificado con evidencias de quema, restos de ceniza compactados, fragmentería cerámica con superficies rasmilladas, instrumentos de molienda, desechos líticos y restos óseos, en un radio de más de $5 \mathrm{~m}$. En este sector, el litoral es rocoso con playas de bolones donde suelen ubicarse diariamente numerosos recolectores de algas. Desde el sitio es posible divisar Punta Patache, al norte, y Pabellón de Pica, al sur. También puede observarse un sendero ascendente que sale desde Chanavaya hacia la cordillera de la Costa.

La estructura registrada en Pabellón de Pica es de forma ovoidal con dimensiones internas de 10,3 $\mathrm{m}$ de largo por $8,5 \mathrm{~m}$ de ancho, totalizando $85,5 \mathrm{~m}^{2}$ (ver Tablas 2, 4 y 5). Los paramentos han sido edificados con piedras sin trabajar y bolones seleccionados $(19 \times 15 \mathrm{~cm})$ del litoral, 


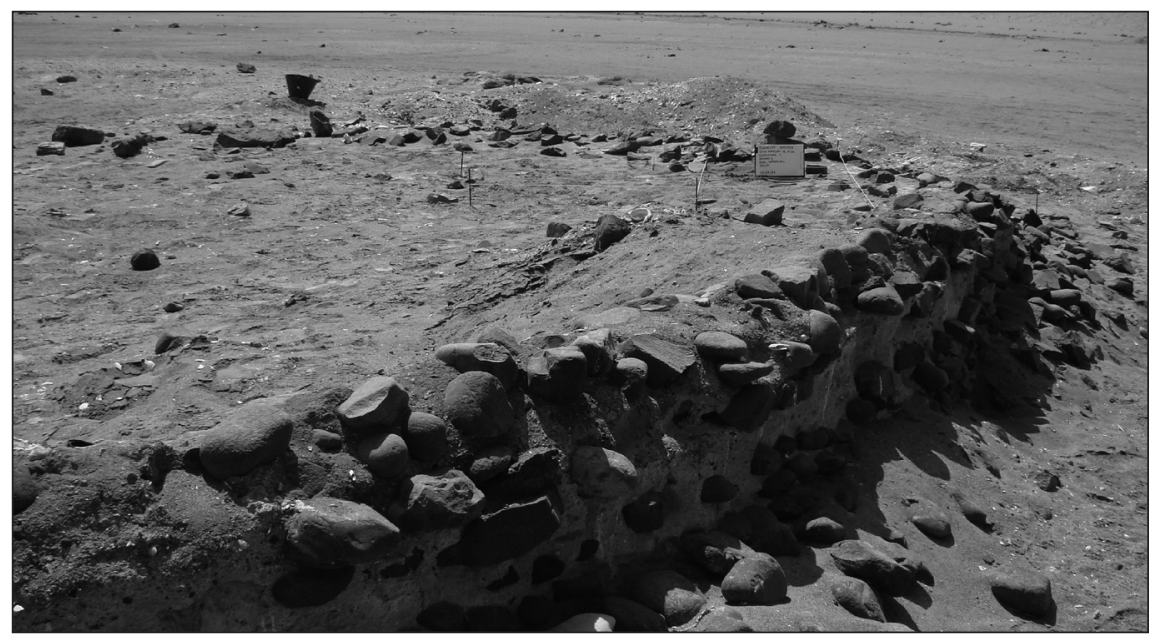

Figura 7. Vista parcial de Pabellón de Pica.

dispuestos en cuidadas hiladas horizontales sobre capas gruesas de argamasa cenicienta. La argamasa o mortero contiene arena fina, ceniza y concha molida y ha sido usada en mayor proporción que elementos constructivos como los bolones de piedra seleccionados. Los tres paramentos registrados corresponden a doble muro con relleno, aplomo y aparejos sedimentarios. El ancho de los muros oscila entre 0,34 y $0,45 \mathrm{~m}$, mientras la altura lo hace entre 0,1 y $0,75 \mathrm{~m}$. No obstante, el alto real de la estructura pudo ser mayor debido a que en la excavación se identificó el piso de la ocupación a 1,2 m bajo la actual superficie. Llama la atención el carácter aislado de la estructura, no obstante, es posible que la apreciación superficial del yacimiento no sea completa, como ocurre generalmente con los depósitos monticulares. El tamaño y la forma curvada de los muros son en conjunto, elementos no registrados hasta ahora en asentamientos costeros en Tarapacá.

Sarmenia. Este asentamiento no documentado en la literatura arqueológica fue detectado mediante prospección sistemática (Ajata 2009 Ms) (UTM: 7735589 N / 378554 E; Figura 8). La terraza marina alcanza una importante amplitud en este sector, superando los 3,6 km E-O. Núñez y Varela (1967-68: 19-20) informan de recursos hídricos ubicados a unos kilómetros al sur de Caleta Sarmenia, en la parte norte de Punta Chucumata justo al pie del barranco de la cordillera de la Costa. Aguada Chucumata se alimenta de aguas infiltradas por la falla, desde las pampas de los salares de Santa Lucía y Soronal, ubicadas al interior.

El sitio se ubica a $36,7 \mathrm{~km}$ al norte de Punta Patache y a $5,2 \mathrm{~km}$ al sur de Caleta Los Verdes, elevándose a 6 m.s.n.m. y enfrenta una playa que cierra por el sur Caleta Sarmenia. Las estructuras prehispánicas se encuentran junto a un complejo residencial actualmente dedicado al turismo, por lo cual el sitio se halla en gran parte disturbado y dos de sus recintos mejor conservados, ubicados dentro del complejo, fueron reutilizados como corrales y bodegas abiertas; incluso, uno de ellos está reedificado. En superficie, el sector presenta abundantes restos malacológicos distribuidos en una extensión considerable por la caleta. También se aprecia fragmentería cerámica (como aquella con "borde en coma" y rasmillados), desechos líticos, restos óseos y basura subactual. En este sector, el litoral es rocoso con bolones y roqueríos de escasa altura. Las ocho estructuras que registramos se emplazan en la suave pendiente de la terraza marina que desciende unos $50 \mathrm{~m}$ hasta el mar. El sitio delimita un perímetro de $2940 \mathrm{~m}^{2}$, con lo cual proyectamos una densidad edilicia de 27,21 recintos por hectárea. La superficie construida intramuros es de $66,68 \mathrm{~m}^{2}$, de tal manera que el FOS alcanza una cifra de $2,26 \%$ de superficie destinada a construcciones (ver Tabla 2). Se distinguen dos estructuras circulares contiguas en el sector sur y otras dos rectangulares más al norte, una de las cuales corresponde a un conglomerado 


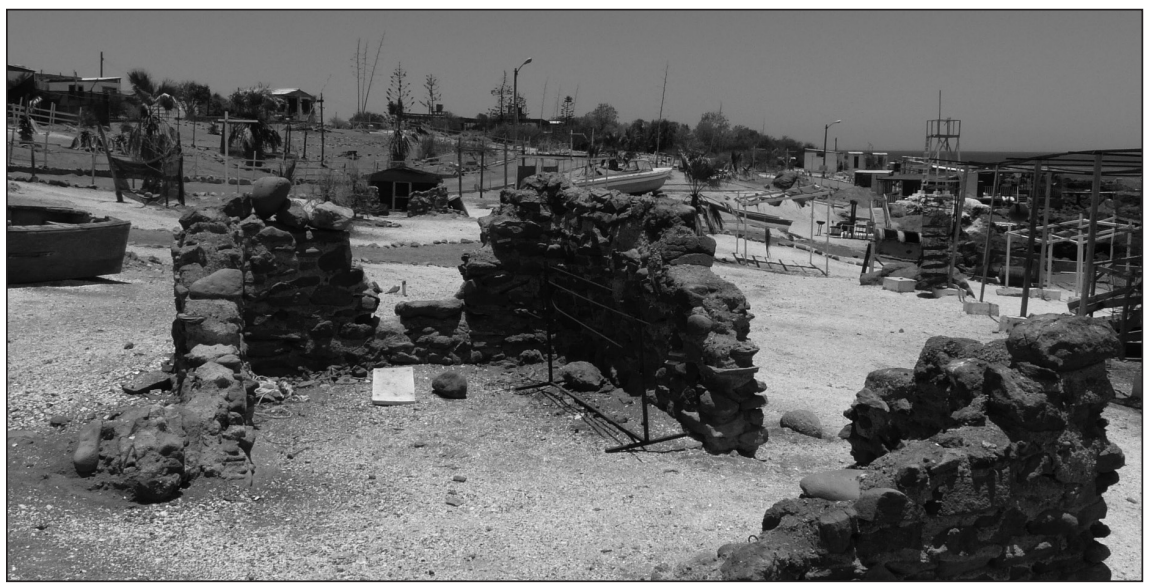

Figura 8. Sarmenia: Vista estructura 5, sector Norte.

compuesto de una estructura rectangular con otras menores adosadas por el exterior.

La clasificación de las formas de planta indica el dominio de estructuras rectangulares $(37,5 \%)$ y circulares $(25 \%)$, aunque las primeras debieran tener mayor significancia debido a que también se registra una estructura subrectangular y otra cuadrada (ver Tabla 4). Las dimensiones mínimas y máximas oscilan entre 2,85 y $17,5 \mathrm{~m}^{2}$, en tanto de acuerdo a los rangos de tamaño, 50\% de ellas posee menos de $5 \mathrm{~m}^{2}$. Siguen dos estructuras ubicadas en el segundo rango $\left(5,1-10,1 \mathrm{~m}^{2}\right)$ y otras dos en el tercero $\left(10,1-20,1 \mathrm{~m}^{2}\right)$ (ver Tabla 5). Las dos estructuras circulares registradas (E.3 y 4) poseen superficies de 4,15 $\mathrm{m}^{2}$ y $4,6 \mathrm{~m}^{2}$, en tanto que los tamaños de las rectangulares tienen superficies evidentemente mayores (E.2: 17,5 m² E.5: 9,7 $\mathrm{m}^{2}$; E.6: $13,5 \mathrm{~m}^{2}$ ). La estructura 6 , reutilizada como corral y bodega, conforma un conglomerado con otra adosada al muro posterior de $3,85 \mathrm{~m}^{2}$ y una segunda, adosada a uno de los muros transversales, cuya superficie es de $2,85 \mathrm{~m}^{2}$. A nuestro juicio, las estructuras circulares y rectangulares definirían dos patrones residenciales que documentarían una ocupación, al menos, bicomponente y prolongada en el tiempo.

Los paramentos registrados en Sarmenia $(n=32)$ indican el predominio de muros simples (59,37\%), aplomados, edificados con aparejos sedimentarios $(18,75 \%)$ y rústi$\cos (12,50 \%)$. El registro más completo ha sido efectuado en las estructuras rectangulares ubicadas dentro del com- plejo turístico. En dos de ellas (E.5 y 6) se identificaron muros de piedras seleccionadas dispuestas en hiladas horizontales unidas con argamasa cenicienta, cuya mezcla incluye carbones, material orgánico y concha molida. En la estructura 5 también se observan en una misma hilada dos huesos cortados utilizados como elementos constructivos. Considerando la totalidad del sitio, el ancho de los muros varía entre 0,2 y 0,67 m, en tanto la altura entre 0,05 y 1,3 m. Con todo, el estado de conservación hace suponer procesos post ocupacionales que han destruido o conservado las estructuras prehispánicas. Aún así, la identificación de dos patrones constructivos es una de las singularidades de este asentamiento.

Los Verdes. Este asentamiento fue estudiado por Sanhueza (1985), quien reconoce una importante diversidad de sitios habitacionales y funerarios prehispánicos. Al norte de Los Verdes se encuentra la Aguada Punta Gruesa, ubicada en el barranco de la cordillera de la Costa, cerca de la cúspide del cerro dominante. A diferencia de aguadas formadas en fallas, ésta se formó a partir de la condensación de nieblas rasantes en el barranco costero. En este sector existen dos registros funerarios asignables al complejo temprano Faldas del Morro, y en el borde del barranco hacia los recursos de agua se ha observado una importante ocupación con cerámica tardía $\left(50 \mathrm{~m}^{2}\right)$ denominada PG-3 (Núñez y Varela 1967-68).

Los Verdes corresponde a un popular balneario ubicado a unos $20 \mathrm{~km}$ de Iquique (Figura 9). Dentro del área de 


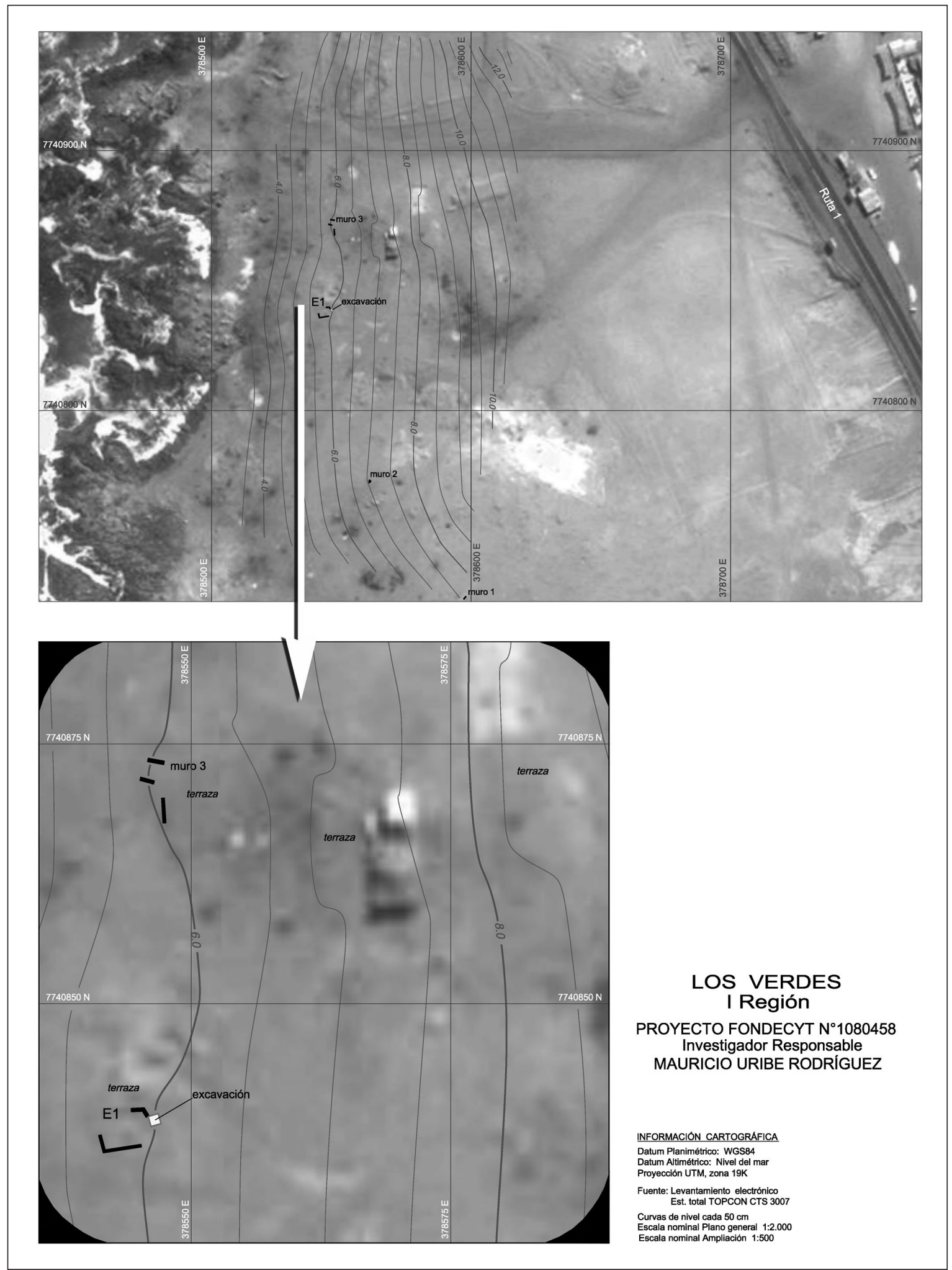

Figura 9. Levantamiento topográfico de Los Verdes. 


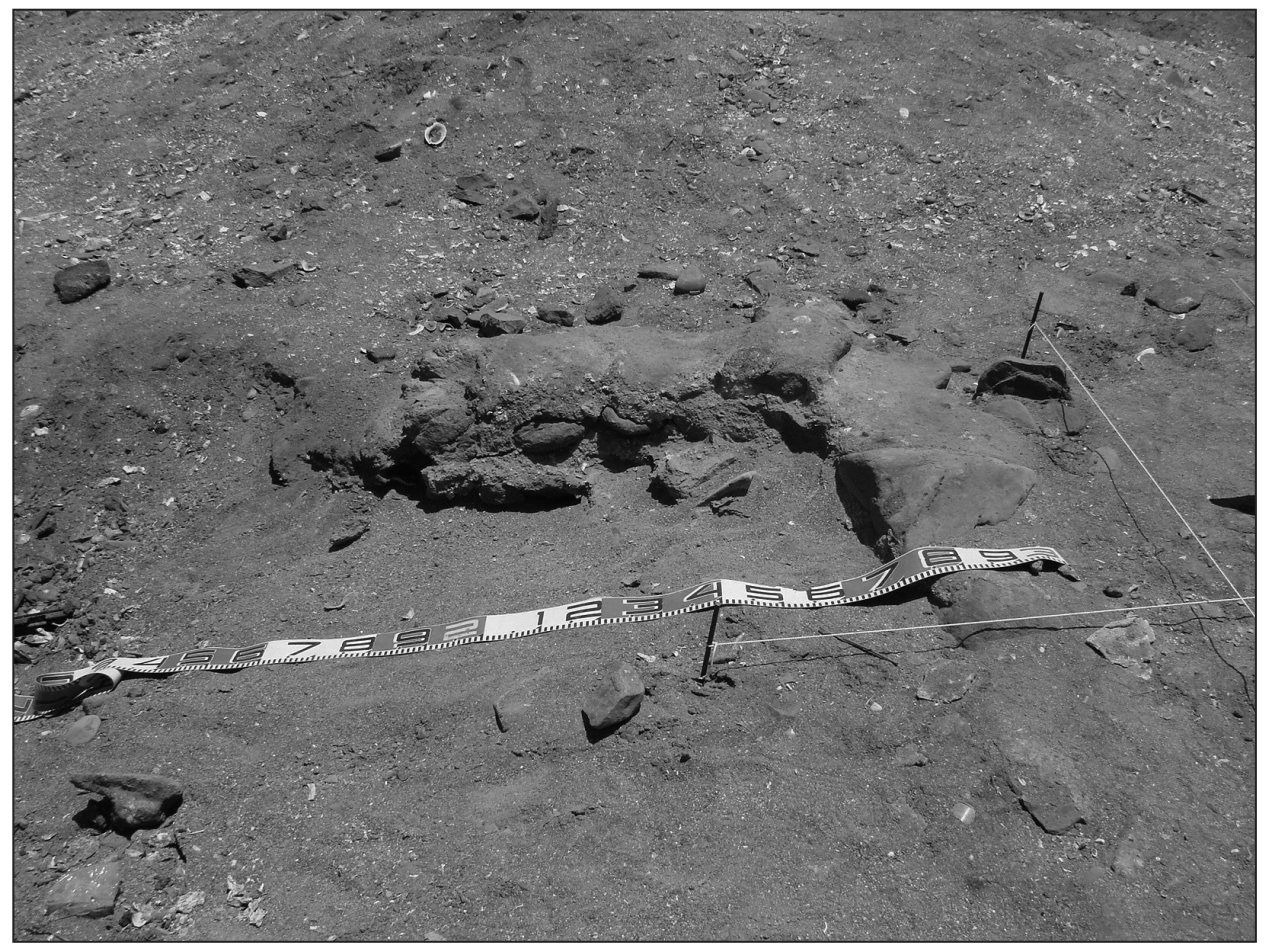

Figura 10. Los Verdes: Vista estructura 1, esquina NE.

instalación de las carpas de los veraneantes se ubican los asentamientos habitacionales descritos por Sanhueza (1985), donde hemos podido ubicar los paramentos de solo una estructura disturbada en su interior, asociada a un depósito de restos malacológicos también disturbados, fragmentería cerámica, restos de textiles, óseos de pescado y basura subactual (UTM: $7740840 \mathrm{~N} / 378550$ E; Figura 10). Se trata de una estructura emplazada en una terraza a 9 m.s.n.m., posiblemente artificial, que delimita un gran conchal a $50 \mathrm{~m}$ del litoral. La estructura es de forma rectangular con medidas internas de 4,3 x 2,85 m $\left(12,26 \mathrm{~m}^{2}\right)$ (ver Tablas 2,4 y 5$)$ y posiblemente fue "huaqueada" en su interior, ya que se observa una gran excavación irregular en el centro, rellena con basuras actuales y junto a ella se ubica un gran montículo de conchas y restos arqueológicos. Los paramentos, registrados en su posición original, y también derrumbados, corresponden a muros dobles en la parte baja y en las hiladas superiores muros simples, aplomados y de aparejo sedimentario (ver Tabla 6). Los paramentos fueron edificados con cantos rodados locales seleccionados por tamaño, aunque sin trabajar. Las piedras están dispuestas en forma ho- rizontal, o acostadas ordenadamente sobre una capa de argamasa muy compacta de color gris y de gran contenido orgánico, que además incluye concha molida, arena, ceni$z a$, restos de moluscos, vegetales y huesos. El ancho de los muros oscila entre 0,3 y o, $4 \mathrm{~m}$, mientras las alturas varían entre 0,1 y o,23 m. En términos funcionales, el espacio estudiado debe corresponder a una estructura habitacional aislada. No obstante, a juzgar por el grado de utilización de esta playa y el continuo paso de automóviles, así como la gran extensión de los desechos arqueológicos, pudieron haber existido otras estructuras en las cercanías de similares características (Sanhueza 1985).

Pisagua $N$. Este asentamiento está ubicado en el área de Punta Pichalo, $10 \mathrm{~km}$ al sur del pueblo actual de Pisagua (UTM: 7837088 N / 373916 E; Figura 11). El sector de Punta Pichalo fue descrito por Bird (1988 [1943]: 80) como una "de las pocas puntas de tierra pronunciadas a lo largo de la costa del norte chileno, proyectándose en ángulo recto a la tendencia general del borde de la playa por una distancia de unos $3,5 \mathrm{~km}$. La punta misma está formada por granito en forma de 


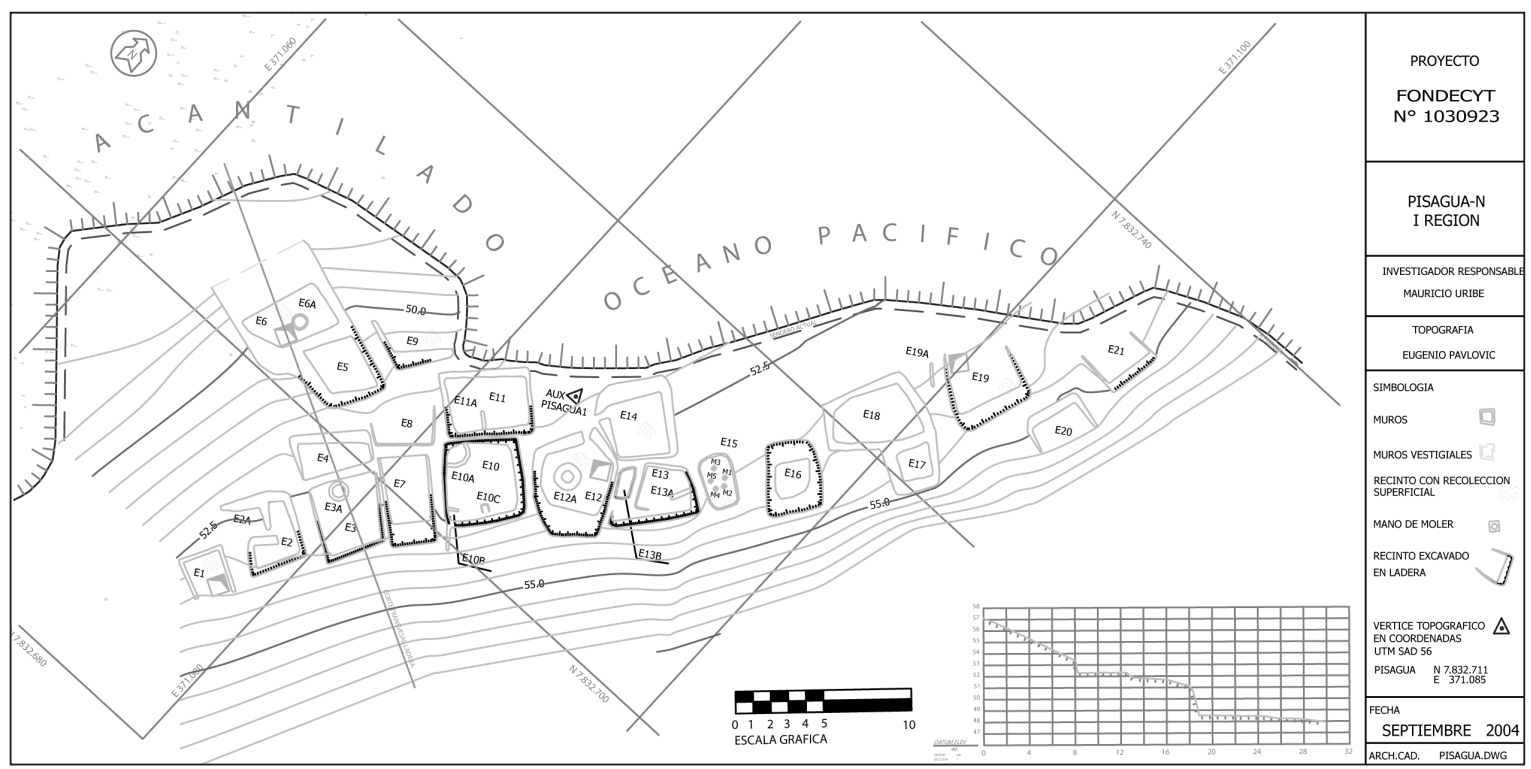

Figura 11. Levantamiento topográfico de Pisagua N.

cresta sumamente escarpada. Esta condición seguramente incidió en la explotación de los recursos marinos y también, el hecho de localizarse en una rica zona de extracción de guano (Núñez y Varela 1967-68). Como han señalado investigaciones previas en la localidad (Bird 1988 [1943]; Moragas 1997 Ms-b), destaca la concentración de yacimientos arqueológicos considerando la inexistencia de cursos de agua o de claras evidencias sobre la existencia de aguadas o vertientes. El sector de Punta Pichalo al sur de la localidad de Pisagua, exhaustivamente trabajado por Bird (1988 [1943]), permitió la vasta descripción de la cultura material de los sitios Brown Refuse y Black Refuse con ocupaciones asignables al complejo Chinchorro desde el período Arcaico Medio en adelante. Los restos arquitectónicos del sitio Pisagua N (Moragas 1997 Ms-b; Adán y Urbina 2008), ubicados a escasos metros, fueron obviados por Bird así como por los trabajos previos de Uhle (1922). El yacimiento fue descrito por Moragas (1997 Ms-b) como un sector de viviendas, sin muchas alteraciones, levantado sobre un basural conchífero en una pequeña explanada apegada a la ladera del cerro que enfrenta al mar. Se trata de un área edificada dispuesta en sentido longitudinal E-O por cerca de $60 \mathrm{~m}$. El rango ocupacional del asentamiento, según las dataciones absolutas, se ubica entre 240 DC y 1420 DC (Tabla 7).
Pisagua $\mathrm{N}$ es un asentamiento habitacional aglutinado, edificado a 20 m.s.n.m. en una planicie levemente inclinada en la que existen dos niveles de aterrazamientos. El conjunto de recintos se ordena longitudinalmente en el sentido de la terraza marina. Sus 25 estructuras ocupan una superficie total de $900 \mathrm{~m}^{2}$, incluyendo espacios exteriores y vías de circulación, lo que indica un alto nivel de concentración edilicia con una densidad de 277 recintos por hectárea. La superficie constructiva del sitio es $432,21 \mathrm{~m}^{2}$, lo que indica una intensidad edificatoria significativa, señalada de igual modo por el índice FOS, que establece un $48 \%$ de la superficie destinada a estructuras (ver Tabla 2). En superficie, destaca la abundancia de materiales culturales entre los que se cuentan cerámica, restos líticos, de molienda, malacológicos, huesos de peces y mucho material botánico. La abundancia de material de molienda señala áreas de intensa actividad en la preparación de alimentos. En efecto, la estructura 20 que probablemente corresponde a un espacio entre recintos, presenta cinco morteros en una superficie de 19 $\mathrm{m}^{2}$. También se observó en el recinto 2 la reutilización de un mortero como elemento estructural de los muros indicando una ocupación prolongada del asentamiento.

En el trazado general de la pequeña aldea Pisagua $\mathrm{N}$ dominan las plantas cuadrangulares $(28 \%)$ y rectangulares 


\begin{tabular}{|l|c|c|c|c|c|}
\hline Sitio & Muestra & Recinto & Estrato & Tipo muestra & Fecha \\
\hline Pisagua N & UCTL 1638 & 19 & $7 \mathrm{~A}$ & Pica-Charcollo (PCH) & $1710 \pm 150 \mathrm{AP}$ \\
\hline Pisagua N & UCTL 1639 & 19 & 14 & Dupont (DUP) & $1040 \pm 95 \mathrm{AP}$ \\
\hline Pisagua N & UCTL 1634 & 6 & $4 \mathrm{~A}$ & Indeterminado (IND 1) & $780 \pm 80 \mathrm{AP}$ \\
\hline Pisagua N & UCTL 1636 & 12 & $4 \mathrm{~A}$ & Pica-Charcollo (PCH) & $645 \pm 50 \mathrm{AP}$ \\
\hline Pisagua N & UCTL 1635 & 12 & $3 \mathrm{~A}$ & Arica no decorado (AND) & $545 \pm 50 \mathrm{AP}$ \\
\hline Pisagua N & UCTL 1637 & 19 & $2 \mathrm{~A}$ & Arica no decorado (AND) & $530 \pm 50 \mathrm{AP}$ \\
\hline Pisagua N & BETA 210435 & 1 & $3 \mathrm{~A}$ & Carbón & Cal. $92-700 \mathrm{DC}$ \\
\hline
\end{tabular}

Tabla 7. Dataciones absolutas ( $\mathrm{Tl}_{\text {y }} \mathrm{C}^{14}$ ) para Pisagua N. Fuente: Adán y Urbina (2008) y Uribe y colaboradores (2007); Proyecto FONDECYT 1030923.

(24\%) (ver Tabla 4 y Figura 11). Un dato de interés es la ocurrencia significativa de plantas trapezoidales (24\%). Las formas cuadrangulares y subcuadrangulares, por su parte, agrupan un $40 \%$ de las formas de planta estudiadas, en tanto que recintos de muros curvos subcirculares y ovoidales alcanzan un $12 \%$. La variabilidad en el tamaño de los recintos de Pisagua N (ver Tabla 5) avala la idea de un asentamiento con cierto nivel de complejidad funcional como también la disposición de ciertos elementos de su cultura material, como los artefactos de molienda, que ya mencionamos. La mayoría de las estructuras presenta tamaños entre el tercer y cuarto rango $\left(20-40 \mathrm{~m}^{2}\right)$, (40\%), seguida de aquellas entre 10 y $20 \mathrm{~m}^{2}(24 \%)$ y, finalmente estructuras ubicadas en los dos primeros rangos (menos de $\left.10,1 \mathrm{~m}^{2}\right)$ con $28 \%$. También existe un gran recinto de más de $40 \mathrm{~m}^{2}$ (ver Tabla 5), lo que indica la existencia de espacios comunales utilizados probablemente como áreas multifuncionales. Esta diversidad de usos es coherente con la idea de un asentamiento permanente donde se efectúan labores cotidianas y productivas en sus inmediaciones. Los muros (ver Tabla 6) son simples y dobles con aparejos mayoritariamente rústicos. Se detectó el uso de una argamasa muy orgánica, probablemente a base de guano y conchas. Otro rasgo de interés son las fundaciones con una profundidad aproximada de $30 \mathrm{~cm}$ y una altura variable de los paramentos sobre la superficie entre 0,1 y $0,7 \mathrm{~m}$. El ancho de los paramentos oscila entre 0,3 y $0,7 \mathrm{~m}$, en la estructura 20. En las excavaciones también se observaron restos de caña enterrada correspondiente a la sección alta y liviana de las paredes (iquincha?).

\section{* Discusión}

\section{Primera época: Sobre el inicio de la tradición arquitectónica costera}

De acuerdo a nuestro análisis, podemos avanzar hacia una nueva caracterización de los patrones arquitectónicos y la evolución de los asentamientos costeros de Tarapacá, así como a una primera mirada a la amplitud y profundidad cronológica de esta "vieja tradición arquitectónica de la costa" que bien percibió Núñez (1970: 56) en el sitio colonial Pisagua Viejo. Lo anterior revierte, de igual modo, la imagen según la cual "en este tramo de la costa desértica no se han conservado los recintos habitacionales correspondientes a los grandes núcleos poblacionales situados en Bajo Molle, Patillos y Los Verdes" (Moragas 1995: 78) y tiene coherencia con un desarrollo de casi dos milenios de una Tradición Arquitectónica Formativa, que se remonta a los momentos tardíos del Arcaico en Caleta Huelén 42. Como ha destacado Llagostera (1989: 70), en la costa arreica se observa una manifestación regionalizada del complejo Camarones que Schaedel (1957: 27) señala como el fenómeno de "poblaciones marítimas con arquitectura" y que identifica para momentos tempranos en el tramo entre Tocopilla y Punta Guasilla.

De acuerdo a los estudios de Muñoz (2003: 488), los patrones arquitectónicos costeros durante fines del período Arcaico (9000-1000 AC), comprenden un recurrente 
uso de materiales perecederos como vegetales, huesos de cetáceos y bolones de piedra en las bases, que no dejan traza arqueológica reconocible, pero que pudieron ser observadas todavía en uso por Vásquez de Espinoza en el s. XVII (Larraín 1974: 69). Las poblaciones costeras de esta época utilizaron asentamientos dispersos con habitaciones de planta circular organizadas en pequeñas caletas, disponiendo sus espacios domésticos sobre basurales conchíferos, algunos de varios metros de altura, especialmente en las cercanías de litorales rocosos y en desembocaduras de ríos. Como señala Muñoz:

\section{“[... durante el período Arcaico se estructuró un tipo de patrón de} asentamiento construido por viviendas de material ligero, cuyas características constructivas estuvieron determinadas por el medio en el cual se levantaban; en hondonadas cuando se encontraban en laderas de cerros y depósitos (conchales) y de base plana, en la terrazas. Se utilizaba, preferentemente, cubiertas de esteras de vegetales en los valles y cueros de mamífero marino en la costa. Este patrón de viviendas en que se utilizó material perecible como fibras vegetales, huesos, piedras y cuero de mamíferos marinos, perduró durante todo el arcaico y siguió arraigado en las caletas de pescadores hasta tiempos históricos[...]" (2002: 489).

Según lo anterior, sostenemos que Caleta Huelén 42 corresponde al antecedente de una tradición arquitectónica que se inaugura en la costa paralelamente al uso de estructuras livianas, como describen Moragas (1995) y Muñoz (2003). Se trata de un patrón habitacional -ya no liviano o ligero, cuyos inicios están datados en 2830 AC-, con depósitos estratificados colmados de restos de alimentos depositados en forma de montículos tapando por completo las estructuras, lo que genera un patrón de abandono sumamente normado. En términos constructivos, la arquitectura bajo el montículo de conchas muestra la preferencia por el uso de pilares de piedra, argamasa de ceniza, pisos selladores y conglomerados de planta circular, con estructuras de dimensiones menores a $10 \mathrm{~m}^{2} .^{11}$ La configuración de los recintos habitacionales

${ }^{11}$ Este tipo de conglomerados de planta circular organizados en torno a un patio central posee una distribución macrorregional ya que es homólogo a la arquitectura de cazadores arcaicos de la modalidad denominada "Arquitectura Formativa de Tierras Altas o Temprana" en Atacama (Adán y Urbina 2007: 25). También se agrega desde un momento temprano a la cotradición Formativa Circumpuneña de "piedras planas" planteada por Raffino (1990) señalando circuitos de movilidad a larga distancia practicados en pequeños conglomerados habitacionales en sectores, refiere a bandas que reutilizan un mismo asentamiento en forma semipermanente durante el ciclo anual o estacionalmente cada año. De acuerdo a Zlatar (1983: 22) en Caleta Huelén 42 "el material cultural es similar en todas las edificaciones y corresponde básicamente a los detectados a lo largo del litoral norte durante el Precerámico Tardío y a lo que podríamos denominar etapa post Chinchorro", por lo cual suponemos que se trata de un patrón que evoluciona con antecedentes costeros próximos. Como hemos planteado, la arquitectura de la costa desértica durante fines del Arcaico (2010 AC-870 AC) adiciona innovaciones a la tradición arquitectónica regional, provenientes del complejo anterior. Ese es el caso de los pisos selladores de argamasa de ceniza de algas bajo los cuales se deposita a los muertos con máscaras de barro, convirtiendo "estos recintos habitacionales también en estructuras funerarias" (Llagostera 1989: 70) y, consecuentemente, vinculando la aparición de la arquitectura en la costa con el culto a los antepasados (Adán y Urbina 2007, 2008).

Luego, los asentamientos estudiados en Punta Patache y sitios del distrito de Cáñamo (Núñez y Moragas 1977 Ms, 1983 Ms) documentan la transición arcaico-formativa en plena costa desértica interfluvial, con un patrón habitacional caracterizado por basurales monticulares junto a afloramientos rocosos (p.e., Patache A, M, N y $P)$ y en ciertas ocasiones presentando estructuras circulares (p.e., Patache G), con episodios fechados entre 2010 AC y 325 DC (Núñez 1976; Moragas 1996 Ms, 1997 Ms-a). En el caso de Patache, las estructuras circulares son de baja altura y poseen superficies que oscilan entre 1,76 y $4,9 \mathrm{~m}^{2}$. Probablemente estas piedras afirmaban puntales y tolderías fáciles de transportar de un lugar a otro en los desplazamientos realizados entre las distintas vertientes costeras (Moragas 1996 Ms, 1997 Ms-a). En Patache G se excavó una estructura circular aislada de muros simples y de 4,9 $\mathrm{m}^{2}$ ubicada junto al conchal, en cuyo interior se enterró el cuerpo de un adulto joven extendido bajo el piso habitacional, el que fue cubierto

desde y hacia la costa del Pacífico, alcanzando inclusive el Salar de Atacama y el noroeste argentino. De hecho, durante fines del Arcaico en el sureste del Salar de Atacama, "en las fases PuripicaTulán y Tarajne las cuentas se confeccionaban preferentemente en conchas del Pacífico" (Núñez et al. 2006: 109). 
por un textil datado en 195 AC. La estructura excavada en Patache G no presentaba piso con sello de argamasa. El patrón de estructuras circulares en áreas de basuras monticulares y próximas a afloramientos tendría representación más al norte, en el sector sur de Sarmenia, el cual presenta dos estructuras contiguas cuyas superficies $\left(4,15\right.$ y $\left.4,6 \mathrm{~m}^{2}\right)$ son semejantes a las de Caleta Huelén y Patache. Considerando lo anterior, creemos que el uso de estructuras habitacionales con entierros bajo los pisos perduró desde el abandono de Caleta Huelén 42, hasta el período Formativo Temprano (900 AC - 400 DC) en la costa arreica. Desde una perspectiva más amplia, podemos agregar que las ocupaciones de Patache y Cáñamo se inician contemporáneamente al uso de Caleta Huelén 42 en el año 2010 AC, como lo indica la datación del estrato precerámico más profundo del montículo Cáñamo 1 (Núñez 1976: 98). Lo anterior apoya el vínculo entre ambos componentes arquitectónicos referidos.

Aunque en Cáñamo y Patache no se registran evidencias habitacionales más tempranas, $16 \mathrm{~km}$ más al norte, en Caramucho 3, se conoce un conchal extendido datado en $4030 \mathrm{AC}$ que contiene restos de anzuelos de cactus y concha y algunas estructuras derrumbadas (Olmos y Sanhueza 1984: 146). ${ }^{12}$ En Patillos 2, se conoce un cementerio excavado por Nielsen antes de 1950, perteneciente a poblaciones Chinchorro Clásicas y Tardías del "complejo Patillos" (Schaedel 1957; Núñez 1965: 30), cuyas ocupaciones finales se estiman entre 3500 y 2000 AC (Moragas 1995; Rivera 2002). Esta última fecha es sincrónica con el inicio de la ocupación en Cáñamo I (Núñez 1976) y las ocupaciones de Caleta Huelén 42. Por otra parte, un dato interesante es la evidencia funeraria en Bajo Molle 2, donde Schaedel (1957) excavó una tumba colectiva de forma circular "compuesta por un cerco de madera de cactus revestido por una especie de estera de ramitas de totora". De esta manera queda bien documentado el sistema de entierro secundario con preparación complicada de los cuerpos (Olmos y Sanhueza 1984: 144), asociado al temprano uso de arquitectura destinada a los entierros, como sucede posteriormente en Caleta Huelén 42 y Pa-

\footnotetext{
${ }^{12}$ Según Moragas, "los asentamientos en la costa desértica interfluvial Iquique-Loa se realizaron preferentemente en ciertos sectores cercanos a aguadas o donde la concentración de neblinas permitía la vida humana. La datación más temprana registrada para el área es de 4030 AC" (1995: 77).
}

tache G. Por último, en Bajo Molle 1, Núñez (1965: 24) describe un basural de conchas extendido y tumbas preparadas en la arena, donde se observan fragmentos cerámicos superficiales, junto a estructuras habitacionales (B-1A) que podrían datar de la época Chinchorro (Olmos y Sanhueza 1984: 144).

En suma, la información discutida avala una continuidad y arraigo de las poblaciones marítimas de fines del Arcaico identificadas con la tradición Chinchorro. Dichas poblaciones, según Olmos y Sanhueza (1985: 149) habitaron, luego de un estable proceso de adaptación, en Bajo Molle, Chucumata, Cáñamo y Patillos, y seguramente estuvieron presentes en Los Verdes y Punta de Lobos en Bahía Chomache. Reutilizaron los mismos asentamientos o se instalaron en sectores aledaños producto de los desplazamientos entre las distintas localidades, de tal manera que se aprecia una franja de intensa ocupación longitudinal durante los siglos posteriores, tanto en la costa arreica como en zonas de desembocadura de ríos (p.e., Pisagua 7 y Caleta Huelén 42). Todo lo anterior tendría dos consecuencias geográficas y culturales significativas. Primero, en la sección costera septentrional de Tarapacá se documentaría la existencia de dos componentes culturales contemporáneos durante la transición Arcaico-Formativo Temprano, donde Rivera señala que:

“[... tanto en Camarones 15 como en Pisagua 7, tuvimos la oportunidad de estudiar entierros de la fase Alto Ramírez (1000-500 $A C$ ), adyacentes a entierros tardios Chinchorro (III) (2000$500 \mathrm{AC}$ ). Estos son los únicos [dos] casos donde los componentes de dos poblaciones diferentes aparentemente coexistían uno junto al otro" (Rivera 2002: 42).

Sin embargo, en la costa sur de Iquique, la situación sería otra y de mayor continuidad, más coherente con la información que ya hemos discutido y con los planteamientos de Olmos y Sanhueza (1984: 152) sobre continuos desplazamientos longitudinales por la costa durante el Arcaico Tardío. Como señalan Núñez y Moragas:

“[...] las tradiciones 'chinchorroides', como las registradas en la desembocadura del río Loa, datadas a los 2830 años $A C$ [...] pudieron dar lugar en etapas más derivadas hacia los años 2010 AC a los primeros componentes precerámicos de Cáñamo" (1977: 44). 


\section{Segunda época: Variabilidad arquitectónica formativa en la costa desértica}

De acuerdo al registro de nuevos asentamientos con arquitectura en el tramo Los Verdes-río Loa, contamos con nuevas ocupaciones formativas que documentan elementos de continuidad e innovación arquitectónica sobre la tradición inaugurada a fines del Arcaico. ${ }^{13}$ En este contexto, el sitio Chomache representa una primera modalidad de asentamiento, no obstante su posición cronológica continúa pendiente. El asentamiento muestra un novedoso patrón aglutinado de planta rectangular, que agrega además elementos ausentes en el período previo, como el aterrazamiento de la superficie y subdivisión interna de los recintos mediante tabiques o subestructuras. No obstante, mantiene el uso de grandes bloques o pilares dispuestos verticalmente como fundaciones de los muros, sobre los cuales se disponen hiladas superiores con piedras de menor tamaño. Esta configuración constituye, evidentemente, un tipo distinto de unidad doméstica al descrito para Caleta Huelén 42, ahora más acotado y compacto, que junto con incorporar nuevos elementos de diseño, mantendría otros heredados de las edificaciones tempranas, como los materiales de construcción, la ubicación junto a afloramientos rocosos, la presencia de esquinas curvadas (E.1) y el tipo de aparejo de los muros. Todo lo anterior denota la transformación de la infraestructura de la vivienda y a la vez una preocupación conservadora por el aspecto final de las fachadas e interiores de las estructuras.

Aspectos relativos a la inversión arquitectónica en Chomache, como el aterrazamiento de la superficie, la presencia de muros dobles, así como la superficie construida del sitio, manifiestan que este conglomerado habitacional demandó, proporcionalmente, mayor trabajo que asentamientos de planta circular como Caleta Huelén 42 (ver Tabla 2) ${ }^{14}$ En consecuencia, la arquitectura de Cho-

${ }^{13}$ Fechas radiocarbónicas de estos asentamientos formativos se encuentran actualmente en proceso de análisis.

${ }^{14} \mathrm{Si}$ se compara Chomache con Caleta Huelén 42, la superficie de esta última es 15 veces mayor (Caleta Huelén 42: $3280 \mathrm{~m}^{2}$ y Chomache: $210 \mathrm{~m}^{2}$ ). No obstante, a pesar de que Chomache posee solo cinco estructuras y Caleta Huelén 42 contaría con 15 (Adán y Urbina 2005), la superficie constructiva de ambas es bastante cercana (SC-Chomache: 63,07 $\mathrm{m}^{2}$ y SC-Caleta Huelén 42: $70,79 \mathrm{~m}^{2}$ ). Finalmente, la densidad edilicia y el índice FOS mache es relevante, ya que documenta no solo una transición arquitectónica, sino también una transformación en la organización familiar de los grupos costeros. Constituye, con certeza, una innovación que se mantendrá, o será contemporánea con aquellas ubicadas en zonas de desembocadura, por ejemplo, en el río Loa (Spahni 1967; Núñez 1971) y en Camarones (Schiappacasse et al. 1989). De igual modo, este patrón se identifica - con algunas diferencias importantes-en sectores sin recursos hídricos de aguadas como Punta Pichalo donde se ubica la aldea de Pisagua N (Adán y Urbina 2008), la cual presenta un patrón aglutinado de estructuras cuadrangulares, rectangulares y trapezoidales principalmente, así como aterrazamiento de la superficie y una densidad edilicia de $277,78 \mathrm{rec} / \mathrm{ha}$, comparable con la de Chomache (238,1 rec/ha). El índice FOS también apunta en esta dirección (ver Tabla 2) si se acepta que se trata de los dos asentamientos más aglutinados de la muestra (Pisagua N: 48,02\% y Chomache: 30,03\%).

Por último, es significativo que tanto Pisagua $\mathrm{N}$ y Chomache estén directamente asociados a un litoral rocoso provisto de depósitos de guano fósil (guaneras), lo cual es coherente con la explotación marítima y también con la apropiación de sectores de explotación de fertilizantes agrícolas destinados a campos de cultivos de valles bajos (p.e. Conanoxa, Tiliviche o Quillagua) o de otros más distantes (p.e., Tarapacá o Guatacondo). No obstante, el rango cronológico de Pisagua $\mathrm{N}$, ubicado entre los años 290 DC y 1470 DC (ver Tabla 7), indicaría la vigencia de este patrón arquitectónico durante el período Formativo Tardío (400 DC-900 DC), con una notoria prolongación al período Intermedio Tardío, aumentando su variabilidad funcional interna e intensificando el uso del asentamiento (ver Tabla 2). En el caso de Chomache, nuestra impresión es que esta asociación cronológica sería válida, pero no del todo aplicable ya que no vemos en Pisagua N pilares fundacionales y el uso profuso de argamasa. En cambio se distinguiría del resto por el uso probable de cañas enterradas y revestidas con barro como de una posible sección aérea de los muros (quincha). Por último, en ambos sitios se evidenciaría la sacralización de los espacios domésticos a través de la depositación de

expuestos en la Tabla 2, expresan las diferencias estructurales y cronológicas en el diseño de estos dos exponentes de la tradición arquitectónica costera. 
ofrendas típicas de la costa (Moragas 1995), como es el entierro de una cabeza de perro junto a un muro en la estructura 19 o el cráneo de mamífero marino en la esquina NE de la estructura 1 de Chomache.

Una versión más expeditiva y liviana de la arquitectura que registramos en Chomache y Pisagua $\mathrm{N}$ sería la de Punta Blanca, que presentaría un patrón cuatro veces más disperso que Chomache (ver Tabla 2), aunque con una mayor diversidad funcional interna (ver Tabla 5). Por otra parte, mantendría el emplazamiento junto a afloramientos rocosos como elemento del relieve circundante incorporado a los espacios domésticos, lo que constituye una marcada tendencia en la costa desde el período Arcaico Tardío y Formativo, desde Patache al río Loa (Núñez y Varela 1967-68; Spahni 1967; Núñez 1971; Moragas 1996, 1997a Ms).

Punta Blanca compartiría con Chomache el uso de plantas subrectangulares, aunque sus muros simples edificados con la técnica de "pirca seca" y adosados a bloques rocosos prescindirían del uso de argamasa preparada, señalando una menor inversión de trabajo en la edificación del asentamiento. De esta manera, se acercaría más a un tipo de arquitectura ligera de larga data en la costa desértica, que introduciría mayor variabilidad al patrón de asentamiento descrito en Chomache o en Pisagua N. Estimamos que esta clase de asentamiento fue, probablemente, producto de la necesidad de realizar estadías cortas en espacios como bahías o pequeñas penínsulas donde se requeriría el uso de habitaciones construidas con materiales transportables (p.e., cuero de lobo marino), semejantes a las tolderías o chozas desarmables descritas por los cronistas en los s. XVI y XVII (Larraín 1974; Muñoz 2003). La localización de Punta Blanca entre Chomache y la desembocadura del río Loa avalan un carácter transitorio o de movilidad residencial más intensa entre localidades provistas de fuentes de agua más estables.

En relación a otros asentamientos datados por radiocarbono, el patrón arquitectónico documentado en Punta Blanca, Chomache y Pisagua N sería posterior a la ocupación Formativa Temprana de Cáñamo 1, denominada fase Cáñamo-Montículo y fechada en 860-820 AC (Núñez 1976: 99) y 870 AC, de acuerdo a muestra obtenida del mismo estrato II del montículo de basuras (Núñez y Moragas 1977: 43). La fecha de 290 DC
(1710 \pm 90 AP; ver Tabla 7) de un fragmento Pica-Charcollo (PCH) en Pisagua N sería, no obstante, previa a la construcción del túmulo funerario Cáñamo 3, que habría ocurrido hacia el 760 DC (Núñez 1976: 101-102), muy próxima a la fecha obtenida en Patache A (325 DC; ver Tabla 1). Pisagua N, por otra parte, sería cronológicamente cercano a dos asentamientos que documentan los inicios del período Formativo en Punta Pichalo. Primero, el conchal expuesto por Bird (1988 [1943]) y vuelto a datar por Rivera (2002: 93), cuyas fechas del primer nivel con cerámica se ubican entre 1040 y 1020 AC. Segundo, el cementerio formativo Pisagua 7 con fechas ubicadas entre 1005 y 745 AC. Por último, en la desembocadura del río Loa, Spahni (1967) y Núñez $(1971,1976)$ reconocieron un conjunto de 210 túmulos funerarios, los cuales presentarían fechas entre $450 \mathrm{AC}$ y $215 \mathrm{DC}$, prolongándose inclusive hasta una fecha Formativa Tardía de 820 DC (Núñez 1976; Moragas 1995: 69).

Con todo, la arquitectura descrita para Punta Blanca y Chomache documenta una modalidad propia de la costa desértica meridional de Tarapacá, donde el ámbito doméstico se encuentra ahora separado de los espacios funerarios como una característica relevante de este período (Ayala 2001), a diferencia del período Arcaico cuando ambos espacios eran uno solo (Llagostera 1989; Adán y Urbina 2008). La construcción de por lo menos 210 túmulos funerarios en la desembocadura del río Loa a partir de 450 AC (Núñez 1976), apoya indirectamente el argumento que provee el registro de asentamientos habitacionales en Punta Blanca, Chomache y Pisagua N, donde observamos una transformación de las unidades domésticas del litoral arreico respecto de los patrones habitacionales y funerarios de la tradición Chinchorro precedente, aunque rasgos conspicuos de esta última no fueron abandonados rápidamente (p.e., pilares, muros curvos y uso de afloramientos rocosos). Ciertamente, en estos tres asentamientos se evidencia una mayor y diferencial inversión de trabajo (Chomache y Pisagua N), la que es menor en espacios de ocupación transitoria o de paso, como Punta Blanca. En Chomache y Pisagua N es evidente una mayor densificación en los asentamientos y una segmentación de los espacios domésticos, reflejada en la diversidad funcional que muestran superficies de asentamiento más acotadas y niveladas artificialmente con ese propósito. Esto habría permitido la formación de pequeñas aldeas con viviendas sumamente aglutina- 
das como en Pisagua $\mathrm{N}$ a finales del período Formativo (Adán y Urbina 2008). Este tipo de asentamiento correspondería a ocupaciones más estables con mayor inversión en viviendas durables y manifestaría también un claro interés territorial sobre ciertos sectores productivos.

Adicionalmente, identificamos una tercera modalidad arquitectónica basada en las evidencias de la estructura 1 de Pabellón de Pica. Como se señaló, constituye un caso particular dentro de la muestra analizada, dado que corresponde a un recinto de grandes proporciones $\left(85 \mathrm{~m}^{2}\right)$ de muros curvos de doble hilera con relleno, que demandó una inversión de trabajo significativa para los estándares costeros. La altura de los muros (más de 1,5 $\mathrm{m})$, la construcción con mayor proporción de argamasa entre los bolones/guijarros seleccionados, y la disposición sedimentaria de las piedras en el aparejo, hacen pensar en un patrón bastante elaborado y distinto al descrito en los sitios anteriores. No sabemos aún si esta clase de estructura abandonó el uso de lajas enterradas manteniendo las plantas ovoidales. Por otra parte, si efectivamente fue un espacio doméstico, destaca su gran capacidad de albergue. Usualmente, interpretamos este tipo de estructuras como corrales, patios comunales o espacios públicos, pero solo si se encuentran acompañados de estructuras ubicadas en rangos de tamaño menores (Adán y Urbina 2007). Para confirmar o rechazar esta hipótesis será necesario excavar el exterior inmediato del sitio y establecer si existen o no, estructuras aledañas a ésta. Con todo, la planta y tipos de muros se reconocen en esta misma latitud, en la quebrada endorreica de Guatacondo, tanto en el sitio homónimo (Mostny 1970) como en Ramaditas (Rivera et al. 199596). De igual forma, presenta una planta similar a las estructuras 280 y 398 de la aldea de Caserones I (Adán et al. 2007: 190). Si fuera éste el caso, podría constituir la residencia de una familia extensa o un espacio comunal (Adán y Urbina 2007).

Por último, una cuarta modalidad que identificamos dentro de los asentamientos costeros, estaría ejemplificada en el sitio Caleta Huelén Alto en la desembocadura del río Loa. Junto con los distintos antecedentes arquitectónicos de este sector, vemos que este asentamiento incorpora funciones productivas más amplias, con la orientación económica no solo marítima que comienzan a tener las poblaciones costeras durante el período
Formativo. En términos generales, correspondería a un sitio habitacional de carácter expeditivo destinado al pernocte de personas (p.e., parapetos), al tráfico costavalle o costa-cordillera de la costa (p.e., senderos que cruzan el sitio) y al procesamiento de materias primas minerales como lo demuestran los numerosos martillos, percutores y trituradores asociados a desechos de cobre en distintas fases de reducción, así como en restos de cuentas y placas de malaquita y material calcáreo distribuidos en diferentes estructuras. La importancia de esta actividad dentro del asentamiento se refleja en talleres o en lugares ceremoniales (p.e., "mocaderos") asociados a áreas despejadas, a bloques de mineral triturado y, al parecer, abandonados de facto. A pesar de la arquitectura expeditiva, el aterrazamiento posee una notable extensión y superficie edificada (ver Tabla 2). No obstante, su patrón disperso y la construcción en piedra sin argamasa, la distribución en sectores a lo largo de $1 \mathrm{~km}$ indicaría una ocupación prolongada en el tiempo. Un elemento destacable es la relativa ausencia de desechos de alimentos o la formación de basurales superficiales como en los asentamientos previos, razón por la cual podría responder a una funcionalidad distinta a la de los sitios habitacionales próximos al litoral. Dentro de los tipos de unidades domésticas definidas, creemos que existirían dos clases de viviendas. La primera, caracterizada por estructuras dispersas o contiguas formando pequeños conglomerados de planta rectangular, subrectangular $y$, en segundo lugar, estructuras dispersas de forma ovoidal y circular cuyas superficies sobrepasan levemente los 10,1 $\mathrm{m}^{2}$. A nivel intrasitio notamos que de 29 estructuras que conforman el sector $\mathrm{N}$ junto a los afloramientos rocosos (conjuntos A y B), cinco poseen planta ovoidal con superficies bajo $5 \mathrm{~m}^{2}$, mientras se registran 11 estructuras de planta subrectangular cuyas superficies abarcan entre $0,83 \mathrm{~m}^{2}$ y 13,64 $\mathrm{m}^{2}$; con ello, creemos que se ejemplifica la situación para el asentamiento en su conjunto.

\section{Tercera época: Consolidación de una tradición, las viviendas costeras}

Aún no sabemos con precisión si contemporánea a la situación anterior o en un momento posterior, en la costa desértica interfluvial surgió un nuevo patrón de edificación en las unidades domésticas, cuya trascendencia perduraría hasta períodos coloniales y republicanos en el 
norte de Chile, dando cuenta a cronistas y posteriormente a arqueólogos, de la larga tradición arquitectónica costera que hemos descrito. En general, esta modalidad comprendería asentamientos emplazados sobre densos conchales en terrenos planos, más cercanos a las actuales líneas de playa y asociados a antiguos sitios costeros con evidencias arcaicas y formativas en su perímetro o edificándose directamente sobre ellos. Nos referimos a Los Verdes, donde la estructura 1 muestra la edificación de recintos aislados o independientes, de planta rectangular con muros dobles elaborados con argamasa cenicienta muy compacta y adherente, y piedras seleccionadas por tamaño dispuestas sedimentariamente o "acostadas". Esta misma situación la hemos registrado en el sector norte del sitio Sarmenia (E.5 y 6), el que además presenta arquitectura de patrón circular semienterrado a pocos metros y en una cota más alta alejada de la playa (sector sur). Las dos estructuras del sector norte de Sarmenia son un importante ejemplo de conservación de esta clase de sitios donde las unidades domésticas toman distancia unas de otras $(29 \mathrm{~m})$ y, entre ellas, además existirían diferencias de envergadura, ya que en ciertos casos ocurre el crecimiento o ampliación de la primera unidad a un conglomerado con la anexión de estructuras exteriores (E.6, 6A y 6B).

El patrón disperso de estructuras de planta rectangular y muros cuidadamente construidos, que suponemos se ve representado en Los Verdes y Sarmenia, tendría, de igual modo, un correlato más tardío en Pisagua Viejo (Núñez 1970: 53) donde:

"[...] las casas presentan paredes bien conservadas con alturas siempre superiores a $1 \mathrm{~m}$, y han sido construidas con piedras de una correcta utilización de sus planos y ángulos, pegados con argamasa a base de ceniza, correspondiendo esta técnica a una vieja tradición prehispánica de la costa [...] estamos en presencia de una zona que representa una larga historia de ocupaciones prehispánicas. En tiempos históricos la población aborigen especializada en la explotación del mar con el complemento de la producción del río, recibió la imposición de régimen administrativo español, a través del sitio que hemos presentado" (Núñez 1970: 56 y 58 ).

Adicionalmente, el emplazamiento en terrenos planos más próximos a la línea de playa, patrón de estructuras dispersas sobre conchal y con acceso directo al litoral rocoso, acercan la arquitectura de Los Verdes al tipo de sitio que hemos descrito en Pisagua B cuyas fechas oscilan entre 1395 y 1445 DC (Uribe et al. 2007; Adán y Urbina 2008). Con todo, se trataría de unidades familiares nucleares, las cuales van segmentándose con mayor rapidez y, por lo tanto, los conglomerados no crecen en todos los casos o no forman asentamientos aglutinados como Pisagua N, sino que generan unidades independientes cada vez que se constituye una nueva familia. Este tipo de unidad doméstica más segmentada tendría por el momento representación en las caletas ubicadas entre Sarmenia y la desembocadura de la quebrada de Tana. Comprendería, en consecuencia, un circuito de asentamientos dispuestos longitudinalmente en la mitad septentrional de la costa de Tarapacá, e incluiría el uso de asentamientos aglutinados en sectores de penínsulas con depósitos de guano fósil entre ellos, como por ejemplo Pisagua N.

\section{$*$ Recapitulación y conclusiones}

El presente estudio ha documentado dos transformaciones importantes en la estructura de las unidades domésticas costeras de Tarapacá. Se plantea un cambio en el modo de ocupación del espacio a partir de fines del Arcaico, denominado analíticamente "primera época", que indica una ampliación importante en las características de los asentamientos habitacionales que, durante el Formativo vemos destinados a tareas productivas (p.e., obtención de recursos marítimos, fertilizantes agrícolas, procesamiento de minerales), a facilitar la movilidad longitudinal (p.e., tránsito entre espacios con recursos hídricos más estables) y, como una tercera variedad hipotética, a funciones comunales o públicas correspondientes a una tradición arquitectónica no exclusiva del ámbito costero de Tarapacá (p.e., Pabellón de Pica). En los extremos de la costa desértica, las desembocaduras de río constituyeron espacios donde quedarían marcados los principales hitos del desarrollo arquitectónico de la costa tarapaqueña. El primero, de carácter aldeano, hacia el norte y más tardío (p.e., Pisagua $\mathrm{N}$ ), y un segundo más meridional, en momentos tempranos, donde a partir de prácticas funerarias que incorporan el uso de arquitectura en la tumbas (p.e., Bajo Molle 2) notamos el inicio de la Tradición Arquitectónica Costera (p.e., Caleta Huelén 42). Esto refuerza con mayores antecedentes nuestra impresión sobre 
el origen de la arquitectura doméstica en Tarapacá ya que "la arquitectura, en cuanto innovación tecnológica, parece estar siendo promovida en aquellos significativos ámbitos de la vida social de las comunidades como es la construcción de los espacios para sus difuntos" (Adán y Urbina 2007: 26).

Considerando la distribución y la variabilidad de los tipos de asentamiento que documentan la Tradición Arquitectónica Costera en la "segunda época", así como la transformación de la vivienda en la "tercera época", reconocemos estar frente a una sociedad costera dispersa en múltiples agrupaciones familiares - de distinto tamaño y con una amplitud territorial significativa-, que durante el período Formativo desarrolla cierta especialización económica y laboral. Esta especialización gira en torno a determinados recursos de subsistencia, productivos (p.e., guano), y otros como la minería y la elaboración de bienes de prestigio que adquieren notable importancia a juzgar por el tamaño e inversión arquitectónica en sitios especializados que forman eslabones funcionales de esta nueva cadena (p.e., Caleta Huelén Alto). Lo anterior no sería del todo consistente con la idea de "sociedades de una larga tradición de adaptación marítima, que persisten sin mayores variaciones desde etapas anteriores a las comunidades Chinchorro" (Sanhueza 1985: 57). Sin embargo, a juzgar por la distinción de dos tipos de unidades domésticas en Caleta Huelén Alto y el recinto oval de Pabellón de Pica, podría ser correcto el hecho que los grupos costeros "comenzaron a recibir tempranos contactos con las culturas más desarrolladas de zonas de economía agropecuaria, lo que en un principio no produjo grandes alteraciones en los patrones culturales litoraleños" (Sanhueza 1985: 57).

Con todo, una sociedad costera como la que describieron los cronistas en los s. XVI y XVII, solo provista de livianas y precarias construcciones transportables (Larraín
1974; Muñoz 2003); luego, la interpretación arqueológica de un temprano arribo civilizador desde el altiplano a la costa desértica, que no reconoció una "capacidad de cambio" en estas sociedades (Núñez 1971; Núñez y Moragas 1977); y finalmente la construcción de una sociedad más conservadora, que habitando por milenios la costa arreica se integró mediana y selectivamente a la nueva economía colonial desarrollada y controlada desde el interior (Sanhueza 1985), son visiones que, realizando un notable aporte al conocimiento de estos grupos, no enfatizaron su complejidad social interna, ubicándolos en un margen geográfico-cultural circundante a otros de mayor trascendencia y no en el centro de su propia historia que, sin duda, tuvo como primer escenario la costa desértica de Tarapacá. ${ }^{15}$

Agradecimientos Este artículo es resultado de los Proyectos FONDECYT 1080458: "Período Formativo en Tarapacá. Progreso y tragedia social en la evolución y la temprana complejidad cultural del Norte Grande de Chile, Andes Centro Sur" y $1030923:$ "El complejo cultural Pica-Tarapacá. Propuestas para una arqueología de las sociedades de los Andes Centro Sur (1000-1450 DC)". Agradecemos a Mauricio Uribe, investigador responsable de dichos proyectos, como también a Eugenio Pavlovic y Roberto Izaurieta por los levantamientos topográficos; a Jonathan Astete por la construcción de las bases de datos, y a todos los que realizaron el lento fichaje de arquitectura en terreno en las campañas de 2003 , 2004, 2008 y 2009.

15 Como señala Sanhueza (1985: 57): “Nuestra hipótesis es que la importancia de la producción marina desinhibe las implantaciones coloniales en la costa árida y que los grupos pescadores originales son medianamente integrados al núcleo foráneo, mientras continúan en un sistema de semisedentarismo con desplazamientos interespaciales para explotación e intercambio, paralelo a la complejidad de los sistemas establecidos de mayor envergadura".

\section{* Referencias citadas}

ADÁN, L. y S. URBINA, 2005 Ms. Arquitectura, asentamiento y organización social en las quebradas tarapaqueñas durante los períodos tardíos. Análisis arquitectónico de los sitios Camiña 1, Laymisiña, Caserones 1, Carora, Tarapacá Viejo y Jamajuga.
Informe de Avance, Proyecto FONDECYT 1030923, Santiago.

2007. Arquitectura formativa de San Pedro de Atacama. Estudios Atacameños 34: 7-30. 
2008. Historia arquitectónica de la localidad de Pisagua (I región, Chile): Una tradición olvidada en los períodos tardíos del área Pica-Tarapacá. En Problemáticas de la arqueología contemporánea, A. Austral y M. Tamagnini (Eds.), vol. 2, pp. 723-734. Universidad Nacional de Río Cuarto, Río Cuarto.

2010. Arquitectura quebradeña del Complejo Pica-Tarapacá: Modos de hacer, opciones de diseño, rasgos significativos y decisiones funcionales. Actas del XVII Congreso Nacional de Arqueología Chilena (2006), vol. 2, pp. 865-876. Valdivia.

ADÁN, L., S. URBINA y M. URIBE, 2007. Arquitectura pública y doméstica en las quebradas de Pica-Tarapacá: Asentamiento y dinámica social en el Norte Grande de Chile (900-1450 DC). En Procesos sociales prehispánicos en el sur andino. La vivienda, la comunidad y el territorio, A. Nielsen, C. Rivolta, V. Seldes, M. Vázquez y P. Mercolli (Eds.), vol. 1, pp. 183-206. Colección Historia Social Precolombina. Editorial Brujas, Córdoba.

AJATA, R., 2009 Ms. Prospección arqueológica de la costa sur de Iquique. Informe de Avance Proyecto FONDECYT 1080458, Santiago.

AJATA, R. y P. MÉNDEZ-QUIRÓS, 2009. Buscando el Formativo en la costa tarapaqueña: Prospección arqueológica y gestión de datos en Sistemas de Información Geográfica. Panel presentado en el XVIII Congreso Nacional de Arqueología Chilena, Valparaíso.

AYALA, P., 2001. Las sociedades formativas del Altiplano Meridional y su relación con el Norte Grande de Chile. Estudios Atacameños 21: 7-39.

BIRD, J., 1988 [1943]. Excavaciones en el norte de Chile. Edición traducida por M. Rivera. Ediciones Universidad de Tarapacá, Arica.

CASTRO, V., F. MALDONADO y M. VÁSQUEZ, 1993. Arquitectura del Pukara de Turi.Actas del XII Congreso Nacional de Arqueología Chilena, vol. 1, pp. 79-106. Temuco.

CARRASCO, C., 2002. Las industrias líticas de Quillagua durante el período Formativo en el contexto del Norte Grande. Estudios Atacameños 22:33-57.

CHANG, K., 1968. Settlement archaeology. National Press Books, Palo Alto.

1976. Nuevas perspectivas en arqueología. Alianza Editorial, Madrid.

DUKE, P., 1996. Braudel and North American archaeology: An example from the northern plains. Contemporary archaeology in theory, R. Preucel e I. Hodder (Eds.), pp. 240-257. Blackwell Publishers, Oxford.

HODDER, I., 1990. Textos de cultura material y cambio social: Una discusión teórica y algunos ejemplos arqueológicos. Boletín de Antropología Americana 21: 24-39.

LARRAÍN, H., 1974. Demografía y asentamientos de los pescadores costeros del sur peruano y norte chileno, según informes del cronista Vásquez de Espinoza (1617-1618). revista Norte Grande 1 (1): $55-80$.

LLAGOSTERA, A., 1989. Caza y pesca marítima (9000 a 1000 AC). En Culturas de Chile. Prehistoria. Desde sus orígenes hasta los albores de la conquista, J. Hidalgo, V. Schiappacasse, H. Niemeyer, C. Aldunate e I. Solimano (Eds.), pp. 57-80. Editorial Andrés Bello, Santiago.

McGUIRE, R. y M. SCHIFFER, 1983. A theory of architectural design. Journal of Anthropological Archaeology 2: 227-303.

MEIGHAN, C. y D. TRUE (Eds.), 1980. Prehistoric trails of Atacama: Archaeology of Northern Chile. Monumenta Archaeologica 7, Institute of Archaeology, University of California, Los Angeles.

MORAGAS, C., 1977 Ms. Continuidad y cambio socio-económico en una ocupación del litoral desértico. Distrito arqueológico de Cáñamo (Norte de Chile, I Región). Memoria para optar al título de Arqueólogo. Departamento de Ciencias Sociales, Universidad del Norte, Antofagasta.

1995. Desarrollo de las comunidades prehispánicas del litoral Iquique-desembocadura río Loa. Hombre y Desierto 9 (1): 65-8o.

1996 Ms. Reconocimiento y trabajos arqueológicos en el sector de Patache, Comuna de Iquique, Chile. Informe Estudio de Impacto Ambiental, Archivo SEIA, Consejo de Monumentos Nacionales, Santiago.

1997 Ms-a. Pisagua: Evaluación de yacimientos arqueológicos. Cordenor Corporación de Desarrollo del Norte, Arica.

1997 Ms-b. 6000 años de ocupación en la costa sur de Iquique: Sector Patache (I región, norte de Chile).

MOSTNY, G., 1970. La subárea arqueológica de Guatacondo. Boletín del Museo Nacional de Historia Natural XXIX (16).

MUÑOZ, I., 2003. Uso del espacio y patrones culturales en las tempranas adaptaciones humanas en la costa del extremo norte de Chile y sur de Perú. Actas del XVI Congreso Nacional de Arqueología Chilena, pp. 483-492. Tomé. 
MUÑOZ, M., R. PINTO, A. MESA y A. MOREIRA, 2001. Oasis de neblina en los cerros costeros del sur de Iquique (norte de Chile) durante el evento El Niño 1997-98. Revista Chilena de Historia Natural 74 (2):389-405.

NAVARRO, M., L. PÉREZ, E. RAND y V. BUGUEÑO, 2010. Un sitio de obtención de agua atmosférica en época prehispánica. Aguada Alto Patache ( $20^{\circ} 49^{\prime} \mathrm{S}$ y $70^{\circ}$ o9' O), sur de Iquique, región de Tarapacá, Chile. Actas del XVII Congreso Nacional de Arqueología Chilena, pp. 83-94. Valdivia.

NIEMEYER, H. y P. CERECEDA, 1984. Hidrografía. Geografía de Chile, vol. VIII. Instituto Geográfico Militar, Santiago.

NÚÑEZ, L. 1965. Prospección arqueológica al norte de Chile. Estudios Arqueológicos 1: 9-36.

1970. Descubrimiento de la aldea española Pisagua Viejo (Provincia de Tarapacá). Ancora 4:52-58.

1971. Secuencia y cambio en los asentamientos humanos de la desembocadura del río Loa en el norte de Chile. Boletín de la Universidad de Chile 112: 3-25.

1976. Registro regional de fechas radiocarbónicas en el norte de Chile. Estudios Atacameños 4: 74-123.

1979. Emergencia y desintegración de la sociedad tarapaqueña: Riqueza y pobreza de una quebrada del norte chileno. Atenea 439: 163-213.

1983. Paleoindio y Arcaico en Chile: Diversidad, secuencia y procesos. Ediciones Cuicuilco, México D.F.

NÚÑEZ L, I. CARTAJENA, C. CARRASCO, P. DE SOUZA y M. GROSJEAN, 2006. Emergencia de comunidades pastoralistas formativas en el sureste de la Puna de Atacama. Estudios Atacameños 32: 93-117.

NÚÑEZ, L. y C. MORAGAS, 1977. Una ocupación con cerámica temprana en la secuencia del distrito de Cáñamo (costa desértica del norte de Chile). Estudios Atacameños 5: 21- 49.

1983. Cerámica temprana en Cáñamo (costa desértica del norte de Chile): Análisis y evaluación regional. Chungara 11: 31-61.

NÚÑEZ, L. y J, VARELA, 1967-68. Sobre los recursos de agua y el poblamiento prehispánico de la costa del Norte Grande de Chile. Estudios Arqueológicos 3-4: 7-41.

OLMOS, O. y J. SANHUEZA, 1984. El Precerámico en la costa sur de Iquique. Chungara 13: 143-154.
PARKER PEARSON, M., 1982. Mortuary practices society and ideology: An ethnoarchaeological study. En Symbolic and structural archaeology, I. Hodder (Ed.), pp. 99-114. Cambridge University Press, Cambridge.

PASKOFF, R., 1978-79. Sobre la evolución geomorfológica del gran acantilado costero del Norte Grande de Chile. Revista Norte Grande 6: 8-22.

RAFFINO, R., 1981. Los incas del Collasuyu. Ramos América, La Plata. 1990. Poblaciones indígenas de Argentina. Editorial TEA, Buenos Aires.

RIVERA, M., 2002. Historias del desierto. Arqueología del norte de Chile. Editorial del Norte, La Serena.

RIVERA, M., D. SHEA, A. CAREVIC y G. GRAFFAM, 1995-96. En torno a los orígenes de las sociedades complejas andinas: Excavaciones en Ramaditas, una aldea formativa del desierto de Atacama, Chile. Diálogo Andino 14-15: 205-239.

SANHUEZA, J., 1985. Poblaciones tardías en playa Los Verdes, costa sur de Iquique, I región, Chile. Chungara 14: 45-6o.

SCHAEDEL, R., 1957. Arqueología chilena. Contribuciones al estudio de la región comprendida entre Arica y La Serena. Centro de Estudios Arqueológicos, Universidad de Chile, Santiago.

SCHIAPACASSE, V., V. CASTRO y H. NIEMEYER, 1989. Los Desarrollos Regionales en el Norte Grande (1000-1400 DC). En Prehistoria de Chile. Desde sus orígenes hasta los albores de la Conquista, J. Hidalgo, V. Schiappacasse, H. Niemeyer, C. Aldunate e I. Solimano (Eds.), pp. 181-220. Editorial Andrés Bello, Santiago.

SPAHNI, J., 1967. Recherches archéologiques a l'embouchure du rio Loa (côte du Pacifique Chili). Journal de la Société des Américanistes 56: 179-239.

TRIGGER, B., 1967. Settlement archeology, its goals and promises. American Antiquity 32 (2): 149-160.

1968. The determinants of settlement patterns. En Settlement archaeology, K. Chang (Ed.), pp. 53-78. National Press Books, Palo Alto

UHLE, M., 1922 Fundamentos étnicos y arqueología de Arica y Tacna. Sociedad Ecuatoriana de Estudios Históricos, Quito.

URIBE, M., L. SANHUEZA y F. BAHAMONDES, 2007. La cerámica prehispánica tardía de Tarapacá, sus valles interiores y costa desértica, norte de Chile (ca. 900-1450 DC): Una propuesta 
tipológica y cronológica. Chungara 39 (2): 143-170.

VIDAL, A. y M. GARCÍA, 2009 Ms. Uso del espacio e interacción con la flora de la costa de Tarapacá. Análisis del material vegetal de asentamientos vinculados al Período Formativo. Informe de avance proyecto FONDECYT 1080458 , Santiago.
WILLEY, G., 1968. Settlement archaeology: An appraisal. En Settlement archaeology, K. Chang (Ed.), pp. 208-226. National Press Books, Palo Alto.

ZLATAR, V., 1983. Replanteamiento sobre el problema Caleta Huelén 42. Chungara 10: 21-28. 